\title{
READING THE WALLS: MASONS' MARKS AND THE ARCHAEOLOGY OF ARCHITECTURE AT SAN ISIDORO, LEÓN*
}

\author{
Therese Martin (University of Arizona)
}

The Royal Collegiate Basilica of San Isidoro de León provides a prime example of a medieval building in which the complicated progress of construction can be read in its masons' marks. ${ }^{1}$ (Fig. 1) This turn-of-the-twelfth-century church in northern Spain boasts more than forty different marks with thousands of examples throughout its limestone masonry. A stone wall is built of horizontal ashlar courses, just as a manuscript page is made up of horizontal lines of

* Support for this study was provided by a Faculty Small Grant from the Vice President for Research at the University of Arizona. Aspects of this paper were presented in 2002 at the 37th International Congress on Medieval Studies, Kalamazoo, Mich., May 2-5, and at the 55th Annual Meeting of the Society of Architectural Historians, Richmond, Va., April 17, in collaboration with Dr. Jennifer Alexander, University of Nottingham. My thanks to Jennifer Alexander for our many stimulating discussions of the vagaries of masons' marks. All translations are mine.

${ }^{1}$ For the study of mason's marks, see the concise overview by Jennifer S. Alexander, "Masons' Marks and Stone Bonding," The Archaeology of Cathedrals, eds. T. TattonBrown and J. Munby, Oxford Committee for Archaeology, Monograph no. 42 (Oxford, 1996), 219-236. See also the acts of the Coloquios Internacionales de Gliptografia (especially Zaragoza, 1982; Pontevedra, 1988; Belley, 1994; Rochefortsur-Mer, 1995); and the individual studies of A. Emery, "The Development of Raglan Castle and Keeps in Late Medieval England," The Archaeological fournal 132 (1975): 151-186, pls. XV-XVIII; José Antonio Ferrer Benimeli, Signos lapidarios en el románico y gótico español (Zaragoza, 1975); Juan Luis Puente López and José María Suárez de la Paz, "Marcas de cantero en la torre y panteón de abades del monasterio de San Miguel de Escalada," Tierras de León 51 (1983): 71-86; J. Jiménez Zorzo, I. Martínez Buenaga, J.A. Martínez Prades, and J. Rubio Samper, "El estudio de los signos lapidarios y el Monasterio de Veruela (Ensayo de una metodología de trabajo)," Seminario de Arte Aragonés 40 (1986): 1-214; J. Capdevila Ramos, "Nuevas consideraciones a tener en cuenta para determinar la paternidad de signos de picapedrero de igual dibujo," Actas VII coloquio internacional de gliptografia (Rochefort-sur-Mer, 1990), 45-55; Yves Esquieu, "Sur les traces des tailleurs de pierre au Moyen Age: pour une lecture plus attentive des marque de tâcherons," Mélanges offerts à Georges Duby, vol. IV, La mémoire, l'écriture et l'histoire (Aix-en-Provence, 1992), 117-129; Jennifer S. Alexander, "The Uses of Masons' Marks and Construction Instructions in Medieval Buildings," Roman, Runes and Ogham: Medieval Inscriptions in the Insular World and on the Continent, eds. John Higgitt, Katherine Forsyth, David N. Parson (Donington, 2001), 211-222. 
script. Blocks of stone, taken together, form a logical, readable whole. Elizabeth Sears, in her recent "Reading Images," points out how commonly art historians use the metaphor of reading art. ${ }^{2}$ She defines reading a work of art as "submit[ting] it to close visual analysis, informed by a knowledge of the specific historical context in which the work functioned, a familiarity with relevant pictorial conventions and their associations, and a grasp of visual genres." ${ }^{\text {"3 }}$ While Sears addresses the legitimacy of the use of reading in terms of imagery, I am interested in applying it to a different aspect of art historical research, that of an archaeological reading of the masonry and its marks. Masons' marks can be recognizable objects, like a bird's head or a carpenter's square, or abstract forms, such as a slash or a zigzag. Often, however, the mark is a letter. At San Isidoro, the presence of sixteen different letters used as masons' marks grants a greater legitimacy to our 'reading' of a building. Reading what is written on the wall, and reading the wall itself, may be seen as a step halfway between the wordless image of a work of art and the imageless words of a work of literature. ${ }^{4}$ The marks invite us to read between the lines, defined by masonry courses, as we analyze the wall for breaks and irregularities that indicate constructive phases.

Of course, what we read on the walls of a Romanesque church today differs dramatically from what would have been read in the Middle Ages. We see the product of late nineteenth- and early twentieth-century restorations, when the prevailing aesthetic was to reveal the purity of the stonework. This aesthetic led to the destruction of much painted imagery, rather than allowing it to remain in a fragmentary state, as today's standards dictate. Often, the walls were painted and probably hung with tapestries, hiding the masonry and its marks. Even if a Romanesque church had not been provided with an elaborate cycle of painted narrative imagery, its walls would have been covered in plaster and whitewashed repeatedly over the years to cover soot and dirt. In some case, fictitious lines of masonry

\footnotetext{
${ }^{2}$ Sears' essay opens the Festschrift dedicated to Ilene Forsyth, Reading Medieval Images: The Art Historian and the Object, eds. Elizabeth Sears and Thelma K. Thomas (Ann Arbor, 2002), 1-7.

${ }^{3}$ Sears, "Reading Images," 1.

${ }^{4}$ Although images may contain explanatory tituli, just as texts may be accompanied by illustrations, neither tituli nor illustrations are essential to the nature of the work.
} 
were painted in red on the white surface, simulating regular (and expensive) cut stones, masking the true stonework beneath, whether rubble or ashlar. We see an example of this type of painting at the Romanesque church of Saint-Sernin in Toulouse, where the stone and brick piers were painted over to resemble ashlar masonry. Disguising the stonework beneath a uniform surface of paint had the effect of masking the marks cut into blocks. After all, masons' marks were meant to be seen during construction only, for the purpose of totting up a day laborer's pay.

Although we regret the loss of painted imagery in earlier restorations, we must be grateful for the removal of plaster that reveals all that can be read in masons' marks. ${ }^{5}$ These signs are the only evidence we have for the lowly stonecutter of the twelfth century. A rare contract may survive for a master of the works, such as Master Mateo, who headed the workshop that made the Pórtico de la Gloria at Santiago de Compostela. For him, we have both a contract of 1168, signed by King Fernando II, and the master's own name inscribed prominently on the lintel over the doorway into the west end of the church at its completion in $1188 .{ }^{6}$ The relevant part of the contract states:

I give and concede to you, Master Mateo, who has the highest position of master of the works of the said Apostle, each year in my half of the coin of Santiago, the pension of two marks each week, and that which may be lacking one week will be supplied the next, so that this pension is worth one hundred maravedis for you each year. This favor and gift I concede to you for the rest of your life, for the betterment of the construction of Santiago and of your own person, and those who see the said construction, watch over it studiously, and work on it diligently. ${ }^{7}$

\footnotetext{
${ }^{5}$ Recognizing that masons' marks can be lost in the repeated plastering and cleaning of the walls over the centuries, I have not attempted to quantify the marks at San Isidoro. Rather, I have divided the church into its constructive areas (wall segments, piers, apses, transepts, west end), and I noted the presence or absence of marks in each.

${ }^{6}$ For a full discussion of Master Mateo with lengthy bibliography, see Carmen Manso Porto, "El documento de 1161 relativo a la supuesta intervención del Maestro Mateo en la construcción del Puente de Cesures," Actas, Simposio internacional sobre "O Pórtico da Gloria e a Arte do seu Tempo," (Santiago de Compostela, 3-8 de outubro de 1988) (Santiago de Compostela, 1991), 103-115.

7 "Dono et concedo Magistro Matheo, qui operis prefati Apostoli primatum obtines et Magisterium in unoquoque anno in medietate mea de moneta Sancti
} 
The inscription on the lintel reads, in part, "[The lintels] of this church of Santiago were put up by Master Mateo who as master of the works produced this portal from its foundations." ${ }^{\prime 8}$ Master Mateo's importance is emphasized by the presence of his name at the main entrance of the church, visible to all who enter through his elaborately sculpted portal. But Mateo is the exception. The workers under him remained nameless, as did the masons at San Isidoro in León. We may be able to identify a master of works at San Isidoro from a tomb inscription that credits Petrus, called Deustamben, with "overbuilding" or "building up" the church. ${ }^{9}$ While the term "superedificavit" is difficult to translate into modern architectural terms, it has been taken to mean that Petrus was responsible for vaulting the church of San Isidoro, a reasonable interpretation. The inscription calls him a bridge builder, and the techniques for vaulting a building and constructing a bridge were not far removed. An 1126 charter shows that Queen Urraca (reigned 1109-1126) had been Petrus' patron. ${ }^{9 a}$ No dates are included in the inscription, but we know from the Pilgrim's Guide to Santiago de Compostela that he had died before it was written c. $1135 .{ }^{10}$ That he received the rare privilege of being

Iacobi refectionem duarum Marcharum singulis ebdomadibus et quod defuerit in una ebdomada supleatur in alia, ita quod hec refectio valeat tibi centum morabitinos per unumquemque annum. Hoc munus hoc donum do tibi omni tempore vite tue semper habendum quatinus et operi Sancti Iacobi et tue inde persone melius sit et qui viderint prefato operi studiosius invigilent et insistant." (Archivo de la Catedral de Santiago, Cart. 7, n. 5) A facsimile of the full document with transcription and Spanish translation is in D.J. Pérez Millán, Privilegios Reales y Viejos Documentos de Santiago de Compostela (Madrid, 1965), vol. 3, n.III, pp1-8.

8 "Ecclesie Beati Iacobi collocata sunt per Magistrum Matheum qui a fundamentis ipsorum portalium gessit magisterium."

${ }^{9}$ The inscription is published in Walter Muir Whitehill, Jr., Spanish Romanesque Architecture of the Eleventh Century (Oxford, 1941), 153. Vicente García Lobo and Encarnación Martín López, De epigrafia medieval: Introducción y Album (León, 1995), 55 and 125, date the tomb inscription to the "renovatio" of the early 13th-century at San Isidoro.

9a See Luis Vásquez de Parga, José María Lacarra and José Uría Ríu, Las peregrinaciones a Santiago de Compostela (Madrid, 1948-49; fasc. ed. 1981), vol. 3, Appendix $3,15-16$

${ }_{10}$ Because of the reference to a bridge on Petrus' tomb, Manuel Gómez-Moreno, El arte románico español, esquema de un libro (Madrid, 1934), p. 106 identified him as Petrus the bridge builder in the Pilgrim's Guide, c. 1135: "Petrus, qui Pontem Minee á regina Hurraca confractum refecit." See Paula Gerson, Annie Shaver-Crandell, Alison Stones, and Jeanne Krochalis, The Pilgrim's Guide to Santiago de Compostela: Critical Edition, vol. 2 (London, 1998), pp. 16 and 155-156. For a discussion of itinerant artists, including Petrus, see Serafin Moralejo, "Artistas, patronos y público en el arte del Camino de Santiago," Compostellanum 30 (1985), 399-430, esp. 398-99. Moralejo's complete works have recently been re-edited in Patrimonio artístico de Galicia 
buried in the interior of the royal church of San Isidoro indicates the unusually high esteem with which he was held, and it underlines his connection to the building. ${ }^{11}$ I would suggest that Petrus was the master of works called in by Queen Urraca when she decided to change the design of the church begun by her aunt from woodenroofed to barrel-vaulted (discussed below).

Despite the anonymity of the masons, we are fortunate at least to have their marks in order to understand a building's construction at its most elemental level. In the Romanesque period, the stones were marked by the masons who shaped them, identifying each individual's work in order to assure payment. Or so we assume, given the absence of documentary sources that explain the meaning of masons' marks in this period. Even two centuries later, a contract such as the one cited by Jennifer Alexander for Lincoln Cathedral is almost unique. In 1306 the dean and chapter of Lincoln and one Richard of Stow agreed in specific terms that carved work made for the Cathedral was to be paid by the piece and plain work by measure. ${ }^{12}$ That is, stonecutters would make their mark on the blocks they shaped, and they would be paid, presumably at the end of each day, for the full measure of worked stones. ${ }^{13}$ The more specialized work of carving capitals would have been remunerated according to the worth of the individual piece. In the marks we can read something of the lives of laborers, men who would otherwise pass into history without leaving a trace. ${ }^{14} \mathrm{I}$ use the masculine noun consciously if

y otros estudios: Homenaje al Prof. Dr. Serafin Moralejo Alvarez, ed. Angela Franco Mata, 3 vols. (Santiago de Compostela, 2004).

11 The tomb was moved to the cloister in the 20th century, but its original location was in the church along the south aisle wall.

12 Alexander, "Masons' Marks and Stone Bonding," 219, citing T. Pownall, "The Origins of Gothic Architecture," Archaeologia 9 (1789): 9.

${ }_{13}$ By contrast, as Jennifer Alexander, "The Use of Masons' Mark," 219, pointed out, see Exeter Cathedral, with very few marks, where the fabric accounts listed wages paid to masons weekly. This meant that they did not have to mark stones individually in order to be paid. See also A. Erskine, "The Accounts of the Fabric of Exeter Cathedral, Part 1, 1279-1326," Devon and Cornwall Record Soc., new ser. 24 (1981).

${ }_{14}$ This study assumes that the majority of stoneworkers were free men. Although there is limited evidence associating captives with medieval church construction, they were most likely set to the lowliest work. See, for example, the Historia Compostellana, written in the first half of the twelfth century: "Of all this [booty] the Irienses gave the fifth part to the bishop [Gelmírez], as well as that which corresponded to him as the owner of the ships. They also turned over to Santiago the captives for hauling stones and other things for the construction of the church." 
cautiously, as we have no evidence for female stoneworkers in the Middle Ages. By contrast, medieval women in Castilla recorded their names as painters of manuscripts, like Ende pintrix (or En depintrix, depending on one's reading of the signature), who worked as an illuminator on the densely illustrated Gerona Beatus Commentary on the Apocalypse of c. $975,{ }^{15}$ and as painters of murals, such as Teresa Dieç around 1320, whose declaration "Teresa Dieç me fecit" appears on several painted cycles at the convent of Santa Clara el Real in Toro. ${ }^{16}$

Masons at San Isidoro identified their blocks with letters, or with one of a dozen easily recognizable shapes (arrow, cross, crossbow, triangle, star, zigzag, diamond, crosier, bird's head) mason's/carpenter's square, blade (Fig. 2) and another handful of forms whose meaning is no longer clear to us (rotated $\mathrm{V}$ with elaborate serifs, volute, double volute, knot, two diamonds connected by a short line, slash, large keyhole, bird's head without features horn). ${ }^{17}$ (Fig. 3) The letters used as masons' marks at San Isidoro are overwhelmingly majuscules: fifteen capital letters to a single minuscule $(\mathrm{A}, \mathrm{B}, \mathrm{D}, \mathrm{E}$, $\mathrm{F}, \mathrm{I}, \mathrm{L}, \mathrm{M}, \mathrm{N}, \mathrm{O}, \mathrm{P}, \mathrm{R}, \mathrm{S}, \mathrm{T}, \mathrm{W} ; \mathrm{h}) .^{18}$ In addition, the minuscule

Emma Falque Rey, ed. Historia Compostellana, Corpus Christianorum Continuatio Mediaevalis 70 (Turnholt, 1988). For the Spanish version, see Emma Falque Rey, ed., Historia Compostelana (Madrid, 1994), 247.

${ }^{15}$ For the Gerona Beatus, see John Williams, The Illustrated Beatus: A Corpus of the Illustrations of the Commentary on the Apocalypse, Vol. 2: The 9th and 10th Centuries (London, 1994), 51-64. For the question of female artists, see the classic study by Annemarie Weyl Carr, "Women Artists in the Middle Ages," The Feminist Art Fournal (Spring 1976): 5-9 and 26, and a more recent summary by Christine Havice, "Women and the Production of Art in the Middle Ages: The Significance of Context," Double Vision: Perspectives on Gender and the Visual Arts, ed. Natalie Harris Bluestone (Madison and Teaneck, 1995), 67-94.

${ }^{16}$ Cited by Melissa R. Katz, "Architectural Polychromy and the Painters' Trade in Medieval Spain," Gesta 41/1 (2002): 3-13, esp. 9-10. The author presents convincing evidence that Teresa Dieç was the painter, not the patron, of the murals.

${ }^{17}$ See the appendix to this article for a complete breakdown of the marks at San Isidoro by location.

${ }_{18}$ Although epigraphic analysis should aid in understanding letter-shaped masons' marks, for León studies of medieval epigraphy are still in an early stage. Some first steps have been taken by Vicente García Lobo, "Las inscripciones medievales de San Isidoro de León," Santo Martino de León, Ponencias del I Congreso internacional sobre Santo Martino en el VIII centenario de su obra literaria, 1185-1985 (León, 1987), 371-398, and Vicente García Lobo and Encarnación Martín López, De epigrafia medieval: Introducción y Album (León, 1995). See also the classic studies of Robert Favreau including Les inscriptions médiévales (Turnholt, 1979) and L'épigraphie médiévale: naissance et développement d'une discipline, Académie des Inscription et Belle-Lettres, Comptes rendus (Paris, 1989). 
"h" appears only in the final phase of construction on the Romanesque church. We find it in just two locations: on the horseshoe-shaped doorway that opened onto the pre-existing space to the west of the church, the so-called Pantheon, ${ }^{19}$ and on the upper story within the palace rooms that were added onto the south side of the royal apartments above the Pantheon. Of these sixteen letters, many are repeated in different forms. Most appear written both correctly and as mirror images (B, D, E, F, L, N, P, R, S). (Fig. 4) In fact, to this list we could add most of the other letters (A, I, M, O, T, W) because they read the same backwards and forwards. ${ }^{20}$ The minuscule $\mathrm{h}$ is the only true exception, as it appears in a single form written correctly. There are three varieties of the S (tiny and curly; elongated; reversed with serifs), three of the $\mathrm{B}$ and $\mathrm{D}$ (normal; reversed; elongated), two of the $\mathrm{O}$ and I (normal; with a tail), and two of the $\mathrm{W}$ (interlocking Vs; omega-shaped). We also have the unusual occurrence of three letters appearing together: $\mathrm{VCO}$ or $\mathrm{OCV}$, written vertically. Jennifer Alexander has suggested that masons who used letter-form marks would have had experience making inscriptions. ${ }^{21}$ These stone-cutters were possibly, but not necessarily, literate. A mason practiced at copying could have been set to reproduce an inscription without being able to understand the words he was carving.

As to whether each mark represents one or more individuals, I think the answer varies according to the mark. If marks are truly identical in execution, they may indeed represent just one mason, as Edson Armi asserts. ${ }^{22}$ Perhaps we may add a nuance to this picture. Given that medieval professions tended to be passed down within the family, perhaps we may assign a mark to a family unit of father and apprentice son/s when there is some variation within the way a mark is reproduced in the same building, such as the three different forms of the $\mathrm{S}$ at San Isidoro. Without contemporary

19 As John Williams has demonstrated, the lower part of the fresco of the Nativity was destroyed when this new doorway was opened into the Pantheon, thus confirming that the frescoes were painted before the church was completed. John Williams, "San Isidoro in León: Evidence for a New History," Art Bulletin 55 (1973): 171-184.

${ }^{20}$ Jennifer Alexander's continuing research into this question indicates that nonliterate individuals (children in this case) see mirror-image letters as the same letter. See her preliminary comment in "The Uses of Masons' Marks," 219.

21 Alexander, "The Uses of Masons' Marks," 221.

22 C. Edson Armi, Masons and Sculptors in Romanesque Burgundy. The New Aesthetic of Cluny III, 2 vols. (College Park, 1983), vol. 1, 11. 
documentation regarding workshop practices, however, this suggestion must remain somewhat speculative.

Although masons' marks were a common phenomenon in the Romanesque period when ashlar masonry became the standard, few churches today preserve as many visible marks as San Isidoro. Many factors can contribute to the loss of masons marks, including cleaning and restoration in the past century, and plastering or the removal of plaster. At San Isidoro, for example, the crossing piers have almost no visible marks. Instead, the striations on the masonry indicate that the stone has been shaved down during one of the church's many restorations in order to remove irregularities, with the unfortunate result that the masons' marks have been all but erased. The absence or presence of marks on sculptural elements can help to draw conclusions about the make-up of the workshop. Marks on capitals, for example, are useful because they tell us whether the same stonecutter made both plain blocks and sculpted works, or whether sculptors worked exclusively on pieces requiring greater expertise. At San Isidoro, there are no marks on decorative work, such as the billet molding found throughout the building, nor can marks be seen on any of the capitals, although stylistic differences clearly indicate different hands at work. The figural capitals are such individual pieces that they would not have required a mark to identify the sculptor responsible. By contrast with a royally-sponsored, urban church like San Isidoro where multiple members of an atelier worked simultaneously, at small rural churches mason's marks sometimes appear on capitals. This is often the case in Cistercian monasteries, where the austerity of the sculptural decoration means that day-laborer mason and sculptor were likely to be one and the same. ${ }^{23}$

We can draw some conclusions about workshops at San Isidoro from the stonework related to that at the Cathedral of Santiago de Compostela. In the transepts of both buildings, we find a most unusual mark in the shape of a crossbow. (Fig. 5) Although caution must be used when attempting to trace the movements of a specific mason from church to church, this particular mark so distinctive and the manner of reproducing the mark so similar that I accept it as the same. ${ }^{24}$ Besides the crossbow mark, other visual evidence for the

${ }^{23}$ I am grateful to James D'Emilio for pointing out to me the example of the Leonese Cistercian monastery of Gradefes, where the capitals have masons' marks.

${ }^{24}$ This is not to say that every instance of a crossbow mark is by this same 
presence of a Santiago workshop at San Isidoro can be seen in the sculpture of the Leonese south transept. The metopes in the form of rosettes are identical to those on Santiago's Platerías doorway. (Fig. 6) This is in contrast, for example, to the metopes on the Cathedral of Jaca, also in the form of rosettes but clearly carried out by a different hand, despite the presence in León of Jaca-style sculpture. Finally, the figural sculpture on the south transept portal and the remaining fragments from the north portal indicate the presence of an expert sculptor, trained in the Toulousan style, who produced figural sculpture for Santiago before working at San Isidoro. ${ }^{25}$ (Fig. 7) The specific manner of rendering drapery folds as parallel half-circles ending in rounded gatherings, the ropy hair and chubby cheeks easily identifies for us the presence in León of a master sculptor from Santiago trained in a Toulousan style. Thus, three levels of medieval stoneworkers can be recognized from the Compostelan workshop at San Isidoro. At the lowest level are the common masons who prepared the ashlar masonry, leaving their marks in order to be paid per measure of stone. One step up are the masons who carried out the decorative details of moldings, metopes, and perhaps certain capitals, such as the plain vegetal ones. This requires more training than the general mason, but the output at this level is repetitive and fairly mechanical. At the top is the master mason/sculptor, whose works are individual, each one unique. ${ }^{26} \mathrm{He}$ was responsible for the façade sculpture and for major historiated capitals, each

mason/workshop. Such variations in execution as the depth of the cut and the size of the mark must be taken into account in determining filiation. For example, in the late Romanesque monastery of Santa María la Real de Aguilar de Campoo, a crossbow mark can be seen in one of the spiral staircases, but this small, delicately carved mark is clearly by a different hand from that at León and Compostela.

${ }_{25}$ For a summary of the scholarly debate regarding sculpture at San Isidoro, see Marcel Durliat, La sculpture romane de la route de Saint-facques: De Conques à Compostelle (Mont-de-Marsan, 1990), esp. 389. See my recent addition to the debate, "Un nuevo contexto para el tímpano de la Portada del Cordero en San Isidoro de León," El Timpano en la Iberia Medieval: Imágenes, Estructura y Audiencia, eds. Rocío Sánchez Ameijeiras and José Luis Senra Gabriel y Galán (Santiago de Compostela, 2003), 181-205.

${ }_{26}$ For the later period, as presumably in the twelfth century, distinctions in nomenclature were rarely drawn between masons and sculptors. See Jean Givens, "The Fabric Accounts of Exeter Cathedral as a Record of Medieval Sculptural Practice," Gesta 30/2 (1991): 112-118; C.R. Dodwell, "The Meaning of 'Sculptor' in the Romanesque Period," Romanesque and Gothic: Essays for George Zarnecki, 2 vols. (Woodbridge, 1987), vol. 1, 49-61; Victor Mortet, Recueil des textes relatifs à l'histoire de l'architecture et à la condition des architectes en France au moyen âge, 2 vols. (Paris, 1911, 1929). 
element requiring some weeks to produce. He needed no mark to identify his works because each was distinct, paid for by the piece.

Moving from the general to the specific, masons' marks, or the lack thereof, help to establish a relative chronology for construction of the royal palatine complex at San Isidoro. The medieval complex consists of the remains of a palace chapel from the middle of the eleventh century; a two-story segment of the palace built c. 1080 to the west of the church (the lower story of which is now known as the Pantheon); a church built c. 1095-1124; a three-story tower built in three phases - c. 1080 , c. 1120 , c. 1150; a chapter room c. 1150; and the remains of a cloister c. 1150 (Fig. 8). There are no masons' marks on the two walls that survive from the earlier chapel on the site, built c. 1055. ${ }^{27}$ These walls were preserved and incorporated into the north and west walls of the Romanesque construction. Neither are there any marks in the so-called Pantheon, nor in the palace chamber above, nor in the contiguous second floor of the tower. ${ }^{28}$ The absence of marks, along with the evidence provided by base profiles, helps to group Pantheon, palace, and lower story of the tower into the same phase of construction, and it dates them to the early 1080s as one of the first examples of Romanesque architecture in Spain. ${ }^{29}$ It was only in the 1090s that masons' marks became ubiquitous in Spanish Romanesque architecture. ${ }^{30}$ As Serafín Moralejo noted, masons' marks are missing from the first constructive phase of the Cathedral of Santiago de Compostela, which dates from the mid 1070s to the mid 1080s, but they can be found throughout the successive phases. ${ }^{31}$

27 See my Queen as King: Politics and Architectural Propaganda in Twelfth-Century Spain (Leiden, forthcoming) for a discussion of the dating of the c. 1055 palatine chapel built by Queen Sancha (d. 1067) and King Fernando I (d. 1063).

28 The groin-vaulted passageway to the west of the Pantheon, along the Roman wall, has arches whose voussoirs are each marked by an equal-armed cross, but these are assembly marks, rather than the type of individual mark that is the focus of this study. Assembly marks, often seen on arches, indicate how stones prepared for specific positions should be set into place during construction.

${ }_{29}$ John Williams' archaeological study of this space "San Isidoro in León: Evidence," 171-184) dated it to the 1080s and placed it under the patronage of the infanta Urraca (d. 1101).

30 This same pattern played out in Norman England, where mason's marks, a rare occurrence before the 1090s, are a common phenomenon in the building boom that followed.

31 Serafin Moralejo, "Saint-Jacques-de-Compostelle: Les origines d'un chantier roman," Chantiers médiévaux (La-Pierre-que-Vire, 1996), 127-143, esp. 141 (also in Patrimonio artístico). 
Because medieval masons' marks are notoriously difficult to interpret due to the paucity of contemporaneous documentation, scholars have previously noted their presence in San Isidoro without making systematic use of them. Although masons' marks alone cannot resolve the confused chronology of San Isidoro, they do serve to clarify the complicated phases of construction. Here I will use masons' marks as an essential link in the chain of evidence that also includes an archaeological reading of the masonry, a stylistic analysis of sculpture, and an examination of the documentary evidence in order to situate the building within its historical context. Taken together, the sum of this evidence explains the commencement of construction on the Romanesque church of San Isidoro in the later 1090s, the destruction but a decade later of the recently built east end, and finally, its reconstruction along a different plan and completion in 1124 .

We can draw some general conclusions about medieval workshop practices by analyzing the placement of masons' marks. For example, of the forty-odd distinct marks in San Isidoro, some appear in discrete places while others such as the arrow, cross, horn, D, E, F, $\mathrm{I}$, and $\mathrm{R}$ are represented throughout the church. These masons (or members of their teams, depending on the manner of executing the mark) worked at San Isidoro from the beginning of construction c. 1095 to its culmination in 1124. Certain marks, such as the arrow and the slash, appear in the first phase of construction (of which bays 1 and 2 west of the crossing survive), as well as the beginning of the second phase (transepts and apses), but are absent from the final moment of the second phase (three western bays of the church, west wall). A mark that regularly occurs in a concentrated area with only random appearances elsewhere throughout the building (such as the triangle, which we see in the first and second south bays and the first north bay west of the crossing piers, then not again until the fifth south bay) may indicate that the mason returned to work on a later phase. More likely, however, is that blocks he carved were left over from an earlier phase and used later. Eight different marks appear exclusively on piers at San Isidoro, while six different marks were assigned exclusively to walls. This division of labor indicates a large number of masons working simultaneously in order for construction to proceed as quickly as possible. It also indicates the presence of a figure of authority who organized the stoneworkers. Although the profession of architect in the modern sense had not yet developed by the twelfth century, there would have been a magister opera who oversaw construction. Presumably, he was directed by a patron 
who gave instructions concerning style ("Build me a transept with sculpture like the one at Santiago..."), who in turn was advised by a cleric in matters of iconography.

Masons' marks confirm the evidence provided by archaeology that construction at San Isidoro did not progress in a straightforward manner from east to west, as scholars have assumed. ${ }^{32}$ Instead, the east end was substantially rebuilt shortly after the apses and first four bays had been built. Excavations occasioned by the removal of the old flooring in preparation for laying new pavement in 1908 and again in 1970 revealed the foundations of the easternmost pier of the original south nave arcade (Fig. 9). ${ }^{33}$ Foundations could also be seen of the wall aligning with the original southern absidiole, which had been removed in order to build the transept in the second phase of construction, hard on the heels of the first. That the absidioles were enlarged during the construction of the transept is also clearly visible because of their lack of alignment with the nave walls to the west of the transept. Other evidence for the change in plan had appeared during Juan Crisóstomo Torbado's restoration of the church at the beginning of the twentieth century, which included the removal of layers of plaster and whitewash that had hidden the masonry. ${ }^{34}$ This revealed a scar on the east side of the south crossing pier where there had originally been a capital. The scar has been misinterpreted as indicating that the nave vaults once sprang from a lower point and that the removal of the capital demonstrated the decision to install higher vaults. In fact, the reason for the elimination of the capital was much less complicated. The capital had been located at the springer of the nave arcade, not the vault, and it was removed

32 The chronology of the Pantheon continues to be the focus of scholarly debate; however, the church of San Isidoro has received little scholarly attention since the first half of the twentieth century, beyond that focused on the portal sculpture. The studies that established the accepted chronology were Manuel Gómez-Moreno, Catálogo monumental de España: provincia de León, 2 vols. (Madrid, 1925), 179-215 and El arte románico español: esquema de un libro (Madrid, 1934), 58-65 and 102-111; Georges Gaillard, Les débuts de la sculpture romane espagnole-León, Jaca, Compostelle (Paris, 1938), 14, 41-48.

33 Juan Eloy Díaz-Jiménez, "San Isidoro de León," Boletín de la Sociedad Española de Excursiones 25 (1917): 81-98; Williams, "San Isidoro in León: Evidence," 171-184.

34 Torbado's restoration included replacement of the most damaged masonry in certain areas, such as around the upper fenestration. Fortunately for us, he was careful to leave his own mason's mark (resembling a bow tie with a letter in the center) and at times to include the medieval mark as well so that the information would not be lost. 
at the time of the construction of the transept in order to turn a simple pier into a crossing pier. ${ }^{35}$ The most obvious indicators for the change in plan are the columns that were placed in front of the windows in the side aisles opposite the first piers west of the crossing. These columns, which have long been recognized by scholars as anomalous, provided the additional support necessary for the change from a wooden roof to a barrel vault. A remnant of a woodenroofed design can be seen in the first transverse arch west of the crossing, which rests on a corbel. The rest of the transverse arches are carried to the floor by engaged columns because they were designed as an integral part of the vaulting system. This shows that the first "weak" pier in the alternating support system was re-used as a support for the vault. Fenestration and buttressing also indicate the change from wooden ceiling to stone vault. The large nave windows of the first two bays west of the crossing were redesigned to be smaller in the three westernmost bays in order to accommodate the placement of exterior buttresses, necessary to support the weight of a vault. Finally, masons' marks provide further evidence of the change in design: witness the third piers from the crossing. These piers, bearing both a greater number and greater variety in marks than the other piers, mark the moment of change from a woodenroofed basilica without a transept to a vaulted one with greatly projecting transept arms. The proliferation of masons' marks suggests that the change in plan brought with it a redoubling of construction efforts and the hiring of many new workers so that the church could be completed as quickly as possible.

When the east end was completed, some masons stayed on, such as the one who identified his work with a capital I with serifs. His mark can be found throughout the east end, on all south bays and piers, and on the last three north piers. New workers were hired on to continue construction so that building could advance as rapidly as the patron's purse allowed. Among the masons was one whose mark resembles a carpenter's square, which appears only on the

35 The reuse of simple piers as crossing piers also conditioned the manner in which San Isidoro's new crossing was covered. Although related churches at Santiago, Toulouse, Jaca, and Frómista have elaborate crossing domes, San Isidoro's crossing has a simple barrel vault. Because the piers were originally intended to sustain the weight of a wooden roof, their foundations were not sufficient to support a dome in their new function as crossing piers. Thus, although a transept was added by the simple removal of one set of piers, the crossing had to be covered with a barrel vault. 
fourth northern pier to the west of the crossing (see Fig. 2). Another elaborate late-comer left his mark - a V rotated and given decorative serifs - only on the three westernmost south piers. The third south pier from the crossing has an inscription at approximately 1.5 meters from today's floor that has gone unnoticed until now. It reads: ERAT DE above the rotated V mason's mark. ${ }^{36}$ (Fig. 10) This appears to be a literate mason making a specific claim for his work, stating that "it was done by" him. The location of the inscription at eye level on the first pier one encounters from the main entrance of the church, the Lamb Portal, points to an importance in its day that is now lost. Perhaps we may conjecture that the inclusion of a mark within an inscription indicates the presence of a master mason.

It is unusual to find a mason's mark as part of an inscription; however, at San Isidoro it occurs twice: the rotated V under ERAT $\mathrm{DE}$ on a pier near the main entrance, and the date 1124 (E[ra] MCLXII) accompanied by a volute-shaped mason's mark on the exterior of the north absidiole. ${ }^{37}$ (Fig. 11) When the date alone appears carved on a building, it is so ambiguous that, without outside evidence, we cannot be certain whether it indicates the end of construction, or the beginning, or the moment of dedication. In general, scholars are inclined to consider a stand-alone date as the end of construction, perhaps by association with funerary inscriptions, in which the date always indicates the end of life. Two inscriptions as brief as San Isidoro's that are accepted as dates of completion can be found at Celada de Roblecedo (ERA MCCXII) and Aguilar de Campoo (ERA MCCLVII). Many inscriptions were more explicit, such as one located at the base of a buttress near the south portal of San Pedro de Duratón (Segovia). It gives the name of the patron, the consecrating bishop, the year (1100) in which it was dedicated, and the name of the master builder. ${ }^{38}$ One envies the fortunate art historian who studies that church. Here at San Isidoro, we have one

36 I have consulted Ana Suárez González, a specialist in medieval Leonese paleography, about this inscription. She stated that the script is consistent with a date in the early twelfth century.

${ }^{37}$ In the twelfth century, Spain continued to use a Roman system of dating that began in $38 \mathrm{BC}$, based on the year Augustus conquered Hispania. Thus, era 1162 is the equivalent of $\mathrm{AD} 1124$.

38 For the full inscription of Duratón, among others, see Pedro Luis Huerta Huerta, "Hablan las fuentes: aproximación documental al edificio románico," Perfiles del arte románico (Aguilar de Campoo, 2002), 27-51, esp. 41. 
clue that contributes to the deciphering of the date: the volute-shaped mason's mark below the inscription is one found almost exclusively at the west end of the building and within the second story of the palace to the southwest of the church. ${ }^{39}$ Although this mark and the inscription are now on the exterior of the north absidiole, the stone on which they appear has been moved, I would argue, from the west end of the church. It measures $27.5 \mathrm{~cm}$ by $25 \mathrm{~cm}$, and there is a filled-in hole of those same dimensions on the west wall in the upper story of the palace. This stone is outlined in black, the manner by which Torbado marked masonry breaks and differing construction phases during his restoration of San Isidoro in the early twentieth century. Whether he moved the inscription or found it already embedded in the apse, Torbado left for us the evidence that this was not its original location. A close examination of the stone reveals that there was once an additional lower line of writing that begins with an $\mathrm{F}^{40}$ Given the space available on this stone, perhaps we may reconstruct this inscription as a statement such as FECIT HOG or FACTA EST, a declaration of responsibility by the mason who drew the volute-shaped mark. ${ }^{41}$ Besides the 1124 inscription, the volute mark does not appear anywhere in the apses. I would argue, therefore, that this particular mark clarifies the meaning of the inscription: it was a commemoration of the date that the church was completed, as its original location at the west end of the church makes clear, by one of the master masons.

${ }^{39}$ This section of the palace was added onto the south flank of the so-called Pantheon. Though the palace was all but erased in the late fifteenth century when much of it was torn down and the monastic library built in its place, two doors from the church into what was once the palace still survive in the west wall of the church. At ground floor, the door is topped by a chrismon tympanum, and it gives access to parish offices. Directly above, the door in the upper story has been filled in. In the walls around both sides of the doors are the masons' marks that allow us to interpret this phase of construction.

${ }^{40}$ Whereas the $\mathrm{E}$ of the upper register bears an abbreviation mark and stands for the word ERA, the F of the lower register has no abbreviation mark and therefore would have been the first letter in a fully written-out word.

${ }^{41}$ For Spanish inscriptions of the eleventh and twelfth centuries that include such statements, see the studies in Los protagonistas de la obra románica, Aguilar de Campoo, 2004, especially José Manuel Rodríguez Montañés, "Los promotores de las obras románicas," 61-89; Miguel Angel García Guinea, "El románico nominado: arquitectos y escultores que dejaron constancia de sus nombres," 91-119; and Pedro Luis Huerta Huerta, "Los artífices materiales de la construcción románica: oficios y funciones," 121-149. 
The importance of the 1124 inscription at San Isidoro has traditionally been discounted because the date falls within the reign of Queen Urraca (1109-1126). Scholars have assumed that the inscription meant something other than the date of completion, something that could not be determined because of its brevity. The inscription seems to me, however, to be one of several indicators of Urraca's patronage, as I have explained in detail elsewhere. ${ }^{42}$ What is more, the date fits perfectly with a point upon which there is general scholarly agreement: the sculpture at San Isidoro was completed by $1125 .^{43}$

In confirmation of the evidence provided by masons' marks and an archaeological reading of the foundations of the building, stylistic analysis of the sculpture indicates that construction on the east end of San Isidoro may have gotten underway as early as c.1095. Documentary sources and the inscriptions on the infanta Urraca's tomb (d.1101, discussed below) have led scholars to identify her as patron. ${ }^{44}$ My research indicates that the infanta undertook to build a new church, for which construction began with the east end and included four completed bays before a new patron decided to alter substantially the design of the building. It was partially torn down and rebuilt by the new patron, whom I identify as the infanta's niece, Queen Urraca (d. 1126). Soon after she came to the throne in 1109 , the absidioles and the first two bays built by her aunt were demolished in order to allow for the addition of a transept. This would have been undertaken by the members of the Compostelan workshop outlined above. As Moralejo noted, the best sculptors left Compostela in 1112, ${ }^{45}$ and it seems evident that they were brought to León to work on the transept of San Isidoro.

42 Therese Martin, "The Art of a Reigning Queen as Dynastic Propaganda in Twelfth-Century Spain" Speculum 80 (2005): 1134-71, and "De 'gran prudencia, graciosa habla y elocuencia' a 'mujer de poco juicio y ruin opinion': Recuperando la historia perdida de la reina Urraca (1109-1126)," Compostellanum (in press, 2005).

43 Durliat, La sculpture romane de la route de Saint-facques, 389.

44 Gómez-Moreno, Catálogo monumental de España, 179-180; Gaillard, Les débuts de la sculpture romane espagnole, 13; John Williams, "León and the Beginnings of the Spanish Romanesque," The Art of Medieval Spain, exh. cat., Metropolitan Museum of Art (New York, 1993), 167-183, esp. 170; Susan Havens Caldwell, "Urraca of Zamora and San Isidoro in León: Fulfillment of a Legacy," Woman's Art fournal 7/1 (Spring-Summer 1986): 19-25.

45 Serafin Moralejo, "Notas para una revisión de la obra de K.J. Conant," Kennenth John Conant, Arquitectura románica da catedral de Santiago de Compostela (Santiago de Compostela, 1983; first ed. Cambridge, Mass., 1926), 221-236 (re-edited in Patrimonio artístico). 
Sculpture surviving from the first phase of construction can be seen on the Lamb Portal and in the capitals of the apses. ${ }^{46}$ These capitals, with crouching figures and winged monsters, are clear evidence of the presence of a workshop from San Martín de Frómista and the Cathedral of Jaca, buildings which were under construction around 1090, as Serafin Moralejo has demonstrated. ${ }^{47}$ This FrómistaJaca trend was linked by Moralejo to León through the medium of the sarcophagus of Alfonso Ansúrez at the Leonese royal monastery of Sahagún, dated 1093. ${ }^{48}$ Recently, José Luis Senra has demonstrated that the sculptor of the Sahagún sarcophagus is more closely tied to a workshop from San Zoilo de Carrión de los Condes, also dating to the 1090s. ${ }^{49}$ Stylistic ties thus indicate that work on the Romanesque church of San Isidoro began by the mid 1090s, when the capitals in the apses were carved. However, as we have seen, archaeological evidence demonstrates that the north and south absidioles seen today form part of the second phase of construction, c. 1110-1124. When the transept was added and the absidioles were rebuilt on a larger scale, many of the capitals from the late 1090s were preserved and reused. One of these capitals, however, can be seen today as a support for the altar in the north apse (Fig. 12). This serves as a reminder that sculptural style as a source for dating must be used with caution, given the ease with which capitals can be shifted and reused. Previous scholarship has depended on varying sculptural styles and a later dedication from 1149 to divide San Isidoro's phases of construction into two, east end and west,

${ }^{46}$ For a listing of all of the capitals and modillions by location, see Antonio Viñayo González, León roman (La-Pierre-que-Vire, 1972), 93-101.

47 The studies of Serafin Moralejo Alvarez have played a fundamental role in clarifying the chronology of Romanesque sculpture in Spain (re-edited in Patrimonio artístico). See especially "Sobre la formación del estilo escultórico de Frómista y Jaca," Actas del XXIII Congreso internacional de la historia del arte (Granada 1973), I (Granada, 1976), 427-434; "La sculpture romane de la cathedrale de Jaca: état des questions," Cahiers de Saint-Michel de Cuxa 10 (1979): 79-106; "Reflejo de la escultura de Jaca, en una moneda de Sancho Ramírez (†1094)," Scritti di storia dell'arte in onore di Roberto Salvini (Florence, 1984), 29-35; "Artistas, patronos y público en el arte del Camino de Santiago," Compostellanum 30 (1985): 395-430.

48 Serafin Moralejo Alvarez, "The Tomb of Alfonso Ansúrez (†1093): Its Place in the Beginnings of Spanish Romanesque Sculpture," Santiago, Saint-Denis and Saint Peter: The Reception of the Roman Liturgy in León-Castile in 1080, ed. Bernard Reilly (New York, 1985), 63-100 (re-edited in Patrimonio artistico).

${ }^{49}$ José Luis Senra, "La portada occidental recientemente descubierta en el monasterio de San Zoilo de Carrión de los Condes," Archivo Español de Arte 265 (1994): 57-72, and "Nuevos hallazgos románicos en el monasterio de San Zoilo de Carrión de los Condes (Palencia)," Archivo Español de Arte 74 (2001): 88-95. 
with some fifty years separating them..$^{50}$ Besides the capitals from the late 1090s, at San Isidoro we can also recognize the CompostelaToulouse style from the early twelfth century. In addition, there is a third style with no recognizable antecedents, which may be a local Leonese atelier. (Fig. 13) Here the variety of styles does not signify an extension over time, with one group supplanting another. Rather, the Compostelan and Leonese teams overlapped, demonstrating the great interest by a wealthy patron in the rapid completion of the building. Thus, the example of San Isidoro indicates that sculptural styles should be used to provide secondary evidence for the different phases of construction, as indicated by changes in the masonry. When masons' marks are present in the numbers we find them in San Isidoro, their analysis can provide more reliable evidence than sculpture for determining the phases of a building's construction.

Beyond the church, masons' marks allow us to reconstruct the chronology of additions to the royal-monastic complex of San Isidoro. The appearance of certain unusual marks, such as the bird's head, taken together with documentary evidence, narrows the date of the chapter room and the final story of the tower to c. 1150. The Romanesque tower was built over the late Roman wall, and its base is solid masonry. The elevated first story can be dated to the 1080s because of the lack of masons' marks and the presence of base profiles identical to those of the Pantheon and the surviving royal apartments above (now known as the Cámara de doña Sancha). In the second story of the tower, the masons' marks coincide with those in the church. Seven different masons' marks are clearly visible in this second-floor room: $\mathrm{P}, \mathrm{D}$, and curly $\mathrm{S}$, which are found throughout all phases of construction in the church; knot, found only in the first two phases; M, A, and volute, found in the west end. (The second story has been rehabilitated as exhibition space, and the third and fourth stories are now under restoration.) The fourth and final story of the tower reached completion in two distinct phases of construction that are clearly visible in masonry breaks and differentiation of masons' marks. The masonry of the fourth story consists of eight

${ }^{50}$ Gaillard, Les débuts de la sculpture romane espagnole, 14, 41-48. Gaillard grouped all of the capitals of apses and transept together. I identify three different ateliers and moments in time, with the Fromista-Jaca workshop at the end of the eleventh century, a later Compostelan workshop in the second decade of the twelfth century, and a Leonese workshop c. 1120. 
neat courses of stonework in which the same seven masons' marks (I, E, T, F, M, P, reversed L) are seen again and again. After the eighth course, a clear break delineates the final phase of tower construction. Here, a new mason's mark in the form of a bird's head appears. ${ }^{51}$ (Fig. 14) This unusual mark appears also in the c. 1150 chapter room in great number and in the east arm of the cloister, which can be dated to the same period, but in no other locations at San Isidoro. The fourth story of the tower is pierced by large twin openings on each of the four sides. These appear to have been built to serve a defensive function as crenellations before being topped by semicircular arches above the eighth course of masonry. The changes in the stonework of the tower appear just at the springing of the arches that were designed to turn the former crenellations into round-headed arched openings more suitable for suspending bells than for defensive purposes. ${ }^{52}$ Stylized vegetal capitals mark these fourth story openings and help to date the tower to the $1150 \mathrm{~s}$ through their resemblance to the new cloister capitals. Where previously there had been a single portico along the north side of the church (contemporaneous with the so-called Pantheon), now three other arms of the cloister were added in the 1150s. Although the Romanesque cloister was torn down in the sixteenth century to make

51 The bird's head mason's mark can also be found in the Romanesque churches of Santa María del Mercado in León and the monastery of Sahagún, and in the Romanesque tower attached to the Mozarabic monastery of San Miguel de Escalada. Because of the unusual nature of this mark, it can be used more successfully than most to trace the path followed by a specific workshop. For Santa María del Mercado, see Francisco Robles Gutiérrez, Monografia del Santuario y parroquia de Nuestra Señora del Mercado, antigua iglesia del Camino (León, 1884); Luis Menéndez Pidal, "La iglesia de Mercado de León," Boletín de la Real Academia de Bellas Artes de San Fernando 31 (1970): 67-68; Arturo Alvarez Alvarez, "Origen y vicisitudes del templo leonés del Mercado," Tierras de León 32-33 (1978): 33-55. For the monastery of Sahagún, see the study in José Luis Senra Gabriel y Galán, "Arquitectura y escultura en los grandes monasterios benedictinos de Castilla y León (1073-1157)," Ph.D. diss., Universidad Autónoma de Madrid, 1996, 203-316. See also María Victoria Herráez Ortega et al., El Patrimonio artístico de San Benito de Sahagún: esplendor y decadencia de un monasterio leonés (León, 2000). For the Romanesque tower at Escalada, see Hortensia Larrén Izquierdo, "Excavaciones arqueológicas en San Miguel de Escalada (León)," I congreso de arqueología medieval española, Huesca, 1985, vol. 2 (Zaragoza, 1986), 103-123.

52 Julio Pérez Llamazares, Historia de la Real Colegiata de San Isidoro, León (León, 1927; facs. ed. 1982) 339, located the original belfry of the church from the terrace above the palace rooms "al oriente, con el muro que dividía la iglesia del panteón y Cámara de Doña Sancha, hacia su extremo norte, estaba la espadaña del templo - aún se ve parte de la misma confundida con la que ahora existe en el mismo sitio." 
way for a two-story Renaissance cloister, many capitals and shafts survive from the 1150s. The elegant and attenuated vegetal capitals, typical of reform orders such as the Augustinians, differ radically from the highly plastic historiated capitals of the church. Construction in the 1150 s also included the addition of a chapter room onto the outside of the north transept, as indicated within the chapter room by the presence of modillions that once supported an exterior overhanging roof. The presence of the bird's head mason's mark and the sculptural style of the capitals confirm that these monastic areaschapter room, cloister, and upper reaches of the bell tower - were built at the same time.

Written evidence, taken together with an archaeological reading of the walls and an analysis of the sculpture, helps to provide fairly precise dating for the phases of construction at San Isidoro. The inscription on the infanta Urraca's tomb credits her with enlarging her parents' church. ${ }^{53}$ This statement must be used with caution because the tomb dates to a general renovation of royal burials that took place around the turn of the thirteenth century, thus well after the church was built and a full century after the infanta's death. ${ }^{54}$ The inscription refers to the infanta as queen of Zamora, a title accorded her by the thirteenth century, but never in use during her

${ }^{53}$ The tomb was destroyed when Napoleon's troops sacked the Pantheon around 1810, but the inscription had been copied by Morales in the sixteenth century (Ambrosio de Morales, Viage por orden del Rey d. Phelipe II. a los Reynos de Leon y Galicia y Principado de Asturias, para reconocer las Reliquias de Santos, Sepulcros Reales, y Libros Manuscritos de las Cathedrales, y Monasterios, [1572], ed. Enrique Flórez (Madrid, 1791 [1765]; facs. ed. Oviedo, 1977). They are published in Walter Muir Whitehill, Jr., Spanish Romanesque Architecture of the Eleventh Century (Oxford, 1941). Whitehill, 151: HIC REQUIESCIT DONNA URRACA REGINA DE ZAMORA, FILIA REGIS MAGNI FERNANDI. HAEG AMPLIAVIT ECCLESIAM ISTAM ET MULTIS MUNERIBUS DITAVIT, ET OUIA BEATUM ISIDORUM SUPER OMNIA DILIGEBAT, EJUS SERVITIO SE SUBJUGAVIT. OBIIT ERA MCXXXVIIII. For a study of the funerary inscriptions at San Isidoro, see Ana Suárez González, “Del pergamino a la piedra? ¿De al piedra al pergamino? (Entre diplomas, obituarios y epitáfios medievales de San Isidoro de León," Anuario de estudios medievales 33/1 (2003), 365-415. Some of the issues have also been addressed by García Lobo, "Las inscripciones medievales de San Isidoro," 371-398; and José Ignacio Gil Pulido, "Los epitáfios del Panteón de los Reyes de San Isidoro de León (999-1159). Problemas históricos," in Santo Martino de León (Ponencias del I Congreso internacional sobre Santo Martino en el VIII centenario de su obra literaria, 1185-1985) (León, 1987), 401-411.

${ }^{54}$ See also the discussion in Suárez, "¿Del pergamino a la piedra?," 402-403, and in this volume the article by Rocío Sánchez Ameijeiras, "The Eventful Life of the Royal Tombs of San Isidoro in León.” 
lifetime. Additionally, the extent of the enlargement is unclear from the term "ampliavit". This epitaph was traditionally used to credit the infanta with the patronage of the Romanesque church until John Williams correctly reassessed "ampliavit" as referring to the addition of the so-called Pantheon to the eleventh-century church built by Fernando I and Sancha. ${ }^{55}$ However, stylistic and documentary evidence, if circumstantial, also points to the infanta Urraca as patron under whom construction on the new church began c. 1095. She cannot have been responsible for the reconception of the church as a transepted basilica, given her death in 1101 and the clear changes in plans and sculptural styles within the church after that date. The infanta's will does not survive, but we can assume from a reference to it in 1103 that she provided generously for San Isidoro, as her sister Elvira had done in 1099. ${ }^{56}$ Her brother Alfonso VI (reigned 1065-1109) tells us that his own liberal donation of castles, churches, villages, and lands in León and Asturias was made to San Isidoro because, after his sister's death:

Urraca could not do it, [so] I do it for the care of my soul and hers so that the faithful of God whose life I maintain and support in this age will be able to have prayers day and night ... ${ }^{57}$

Thus construction on the new church could easily have continued after the infanta Urraca's death in 1101 with the additional wealth from her will and from Alfonso's magnanimity. However, it is not until 1110 that we find direct documentary support for the physical evidence described above. One year after the death of Alfonso VI and the accession of his daughter Urraca to the throne, we have a document that makes an explicit reference to construction at San Isidoro. We are fortunate that this charter survives, even if the

${ }_{55}$ Williams, "San Isidoro in León: Evidence," 179.

${ }_{56}$ Published in Encarnación Martín López, Patrimonio cultural de San Isidoro de León: Documentos de los siglos X-XIII (León, 1995), 36-38, ASIL 81, donation of Alfonso VI "quomodo meas germanas per suos placos uel testamentos seu alias legitimas scripturas definierunt." Elvira's will is ASIL 132, published in Martín López, Patrimonio cultural de San Isidoro, 34-36.

57 Published in Martín López, Patrimonio cultural de San Isidoro, 36-38 ASIL Cod. 81, "morte mea germana domna Urraca facere non potuit, facio ego pro remedio animae meae atque suae ut et ipsos Dei fideles quorum uita sustentor et subleuo in hoc seculo orantes die notuque possim habere, ut eorum praecibus munitus patrocinio beati Pelagii martiris et beati Isidori confesoris merear sociari in celo per numquuam finienda secula seculorum amen." 
mention of construction is so brief as to be rather tantalizing than explanatory, a far cry from Fernando II's explicit donation to Master Mateo at Santiago de Compostela. On October 13, 1110, Diego Alvitiz, a member of the queen's court, sold some of his property in León and gave the proceeds, "one hundred of the queen's gold coins," to San Isidoro, with the specific statement that the money was given "in illo labore Sancti Ysidori ad illos magistros." the meaning of medieval Latin terms can often be rendered in different ways, Diego Alvitiz's donation is a straightforward gift to "the masters (master masons?) for the construction of San Isidoro." Thus, one moment in the building history can be established precisely: the church was certainly under construction in 1110 , one year after Queen Urraca's accession to the throne.

A third document seems to respond to the need for funding of the basilica at the height of construction. In 1117, Queen Urraca gave to San Isidoro the monastery of San Salvador de León, with all its dependent villages, churches, monasteries, inheritances, and possessions. Although it is not specified, this rich source of income could have been used to subsidize construction. Urraca did indicate that she was providing for the future of the church, stating an unusual three times in the course of the charter that her donation was given to the clerics both of the present and of the future of the church of San Isidoro.

I give this to you for the remission of my sins and those of my relatives and so that you will always remember me and them, both you present today and those who will take charge of the church of San Isidoro after you. In prayer and charity, your memory of us will always live, once the burden of my flesh has passed." ${ }^{, 59}$

Here the queen lays out two important reasons for her patronage of San Isidoro: remission of sins and permanence of memory made

58 Archivo Histórico Nacional, Clero, 3427/7, published in Martín López, Patrimonio cultural de San Isidoro, 39. Also in Luciano Serrano, Cartulario del monasterio de Vega, con documentos de San Pelayo y Vega de Oviedo, Madrid, 1927, 37-38.

59 "Concedo illud uobis ob remisionem pecatorum meorum et meorum parentorum ut et me et eos semper in memoriam habeatis tam uos presentes quam etiam illi qui eidem ecclesiae Sancti Isidori post uos ministraverint et in oratione et elemosina uestra memoria nostri iam exacto onere meae carnis semper uiuat, amen." ASIL 81, published in Martín López, Patrimonio cultural de San Isidoro, 40-42; Cristina Monterde Albiac, Diplomatario de la reina Urraca de Castilla y León (1109-1126) (Zaragoza, 1996), 175-178; Irene Ruiz Albi, La reina doña Urraca (1109-1126), cancillería y colección diplomática (León, 2003), 492-494. 
concrete in a site designed to last forever. In fact, the basilica completed by Queen Urraca has come down to us nearly as it was in her day, with the only major change being the addition of a raised choir in the fourteenth century and the replacement of the main apse in 1513.

Documentary sources also explain the outward sign of change brought about by the shift from defensive tower to campanile, recognizable also in a much smaller scale through the arrival of the bird's head mason's mark. In 1148, the infanta Sancha (d. 1159) and her brother Alfonso VII (d. 1157) brought Augustinian canons to San Isidoro, replacing the nuns of the traditional double monastery and initiating a new burst of construction on the monastic buildings more than two decades after the completion of the basilica. Queen Urraca's children were generous patrons of the new canons, making ten donations to San Isidoro between 1148 and 1158, of which five were joint gifts, four by the infanta alone, and only one by the king alone. They turned over to the new canons the church and all associated buildings, inheritances, income, and possessions that had belonged to the nuns of San Pelayo. ${ }^{60}$ This decade of generosity followed a two-decade long fallow period: after Urraca's death in 1126, her children had made only a single donation to San Isidoro in $1131 .{ }^{61}$ The renewed royal patronage coinciding with the installation of Augustian canons in 1148 is clearly evident in charters, sculptural style, and mason's marks.

After the canons took up residence at San Isidoro in 1148, they began to keep an obituary that provides concrete evidence for defining the patrons of San Isidoro. ${ }^{62}$ Only three members of the royal family

\footnotetext{
${ }^{60}$ For the history of the female convent, see García M. Colombás, San Pelayo de León y Santa María de Carbajal: Biografia de una comunidad femenina (León, 1982).

${ }_{61}$ Published in Martín López, Patrimonio cultural de San Isidoro, 48-50 (1131) and 71-90 (1148-58). Sancha began to draft a will c. 1140-1144 that shows she was already making provisions for further construction on the monastic complex of San Isidoro. She must have been ill at the time, and while her recovery meant that this will was left incomplete, we can see from her 1148-1158 donations that she carried out her intention of funding San Isidoro. See María Encarnación Martín López, "Colección documental de la infanta doña Sancha (1118-1159): Estudio crítico," León y su historia, vol. VIII, Colección fuentes y estudios de historia leonesa, no. 99 (León, 2003), 290-291.

62 The obituary and other early manuscripts of San Isidoro have been studied by Ana Suárez González in Los códices III.1, III.2, III.3, IV y V (Biblia, Liber capituli, Misal) (León, 1997). I am grateful to the author for the assistance she has offered me on questions of paleography at San Isidoro.
} 
were originally recorded in the twelfth-century obituary: Fernando I (d. 1065), Queen Urraca (d. 1126), and the infanta Sancha (d. 1159). ${ }^{63}$ Their obits in the Liber capituli are equal in simplicity to those of the other socii of San Isidoro recorded in the twelfth century. ${ }^{64}$ Queen Urraca's, for example, reads, "Obiit famula Dei regina dompna Vrraca. Era MCLXIIII" (The handmaid of God, the queen doña Urraca died 1126. ${ }^{65}$ These three royal figures must have been included in the original twelfth-century obituary because they were remembered by the canons as the most important patrons of San Isidoro: Fernando I brought the relics of the Visigothic bishop to León, Urraca built the grand church, and the infanta Sancha brought the canons themselves to the site.

As this study seeks to demonstrate, masons' marks can be extremely important for resolving questions of both relative and absolute chronology. When rigorously recorded and analyzed, they reveal the internal logic of a building's construction, providing significant primary documentation essential to the understanding of phasing. The routine inclusion of masons' marks as part of the archaeological analysis of the masonry, in conjunction with a stylistic analysis of the sculpture and a critical examination of the documentary evidence, allows us to read a Romanesque building as though it were an open book.

63 This fact has been noted by Julio Pérez Llamazares, "La Catedral de León, III: Adiciones al Martirologio de los reglares," Anales del Instituto de León 12 (1919): 368 and Vida y milagros del glorioso San Isidoro, Arzobispo de Sevilla y patrono del reino de León (León, 1924), 203; and Luisa García Calles, Doña Sancha, hermana del emperador (León, 1972), 55. The infanta Urraca's obituary was added to Codex III.2 of the Archivo de San Isidoro in the early thirteenth century, but it was not part of the original twelfth-century obituary. As published by Suárez González, Los códices, 308, it reads, "Obiit famula Dei sapientissima domna Vrracha, regina de Zamora, que ampliauit ecclesiam istam et multis muneribus ditauit, filia regis magni Fredenandi et Santie regine, que requiescit in ecclesia ista. Era MCXXXVIIII." The prolixity of this obit is typical of the thirteenth-century additions.

${ }^{64}$ Fernando and Urraca were listed in the Obituary when it was first put together c. 1150. Sancha was added after her death in 1159. According to Suárez González, Los códices, 333. It was only from the beginning of the thirteenth century that the obits began to include references to the specific donations that earned the honor of inclusion in the Obituary.

${ }^{65}$ Suárez González, Los códices, 438. 


\section{APPENDIX OF LOCATIONS OF MASONS' MARKS AT SAN ISIDORO, LEON}

Pier numbering begins to the west of the crossing piers (e.g. N1 is the first north pier to the west of the crossing) because the crossing piers were shaved down in earlier restorations. The south crossing pier shows no visible masons' marks, while the north shows only $\mathrm{R}$ and reversed D. "Bay" refers to a segment of the nave wall.

South bay 3 is the Lamb Portal.

North bays 4, 5, 6 survive from the c.1055 church and have no mason's marks.

1. knot - north \& south apses; transept; N1, N2, S1, S2; south bays 1, 2; possibly north bay 1 ; upper tower room

2. arrow - north \& south apses; transept; N1, N2, N3, N5; S1, S2, S3, S4, S5; north \& south bays 1, 2; west wall; 2nd story of west wall, palace side

3. slash - north \& south apses; transept; north \& south bays 1, 2

4. Greek cross (with and without serifs) - main, north \& south apses; transept; N1, N2; north bays 1, 2; south bays 4, 5, 6; west wall

5. P (normal and reversed) - south apse; transept; N1 (only on drum above marble shaft thus part of later refitting of pier to support vaulting), N3, N4, N5; S2, S3, S4, S5; pier in front of window between north bays 1 \& 2; north bays 2; corner joining new wall to c. 1055 wall; south bay 1; west wall; 2nd story of west wall, palace side; upper tower room; bell level of tower

6. crossbow - north \& south apses; transept; south bays 1, 2 (no piers)

7. I - south apse; transept; N3, N4, N5; S1, S2, S3, S4, S5; south bays 1, 2, 4, 5, 6; bell level of tower

8. I with tail (long and short) - transept; N2; south bay 2; corner of north wall \& transept (short)

9. E (normal and reversed) - main, north \& south apses; transept; north bay 1 ; south bays 1, 2, 3, 4, 5; only mark found on Lamb Portal 
10. volute - north apse only on 1124 inscription; transept; south bays $1,4,5,6$; west wall; 2 nd story of west wall, palace side; upper tower room; bell level of tower

11. horn - main, north \& south apses; transept; N2, N3, N4; S3, S4, S5; north bay 3; south bay 1

12. B (normal, reversed \& elongated)- transept; N1 \& N2, N4 (elongated); south bays 1, 2

13. double volute - transept; south bay 1

14. curly S (normal and reversed) - transept; south bay 1; west wall (esp. on horseshoe-shaped doorway); upper tower room

15. reversed $\mathrm{S}$ with serifs $-\mathrm{N} 1, \mathrm{~N} 2$

16. elongated $\mathrm{S}-\mathrm{S} 2$

17. triangle - north bay 1; south bays 1,2, 5

18. star - north bay 1; south bay 1; chrismon doorway; 2nd story of west wall, palace side

19. zigzag — north transept; north bay 1; south bays 1, 2, 3, 6; west side of buttress on chrismon doorway

20. diamond (double and single) - north apse; north transept; possibly N2 (single)

21. L- south bay 6

22. $\mathrm{N}$ (normal and reversed)- $\mathrm{N} 1, \mathrm{~N} 2 ; \mathrm{S} 1, \mathrm{~S} 2$

23. M-west wall (esp. on horseshoe-shaped doorway); possibly on south corner wall \& transept near curly S; upper tower room

24. W (reminiscent of double volute)- south apse

25. W (two intersecting $\mathrm{Vs}$ ) - exterior south transept

26. D (normal, reversed and elongated) - north crossing pier (reversed), N1, N2, N3, N4, N5; S2, S4 (elongated), S5 (normal \& elongated); south bay 5 (elongated); west wall; horseshoe doorway; 2nd story of west wall, palace side (elongated); upper tower room

27. V rotated with fancy serifs - S3 (normal and with ERAT DE), S4, S5; south bay 5

28. F (normal and reversed) - corner joining new wall to c.1055 wall; south bays 4, 5, 6 above stringcourse (reversed); N1 (reversed), N2 (normal \& reversed), N3, N4, N5; S3, S4, S5; bell level of tower (normal \& reversed)

29. R (normal and reversed) - north crossing pier, N1, N2, N3, N4; S3, S4, S5; west wall

30. $\mathrm{h}$ - horseshoe doorway; 2nd story of west wall, palace side

31. crozier - horseshoe doorway

32. $\mathrm{O}-\mathrm{N} 1, \mathrm{~N} 2$; south bay 4 above stringcourse 
33. O with tail - south bays 4, 6 above stringcourse

34. mason's tool- $\mathrm{N} 4$

35. blade $-\mathrm{N} 1$

36. $\mathrm{T}$ - north apse

37. A-horseshoe doorway-interior of Pantheon (same as A in ERAT DE); upper tower room

38. VCO, OCV ( $\mathrm{C}$ or volute?) - exterior of south apse on blind arch and window

39. bird's head without features (?) - N2

40. large keyhole - clerestory

41. bird's head - above springing of arches only at bell level of tower; chapter room; east arm of cloister 


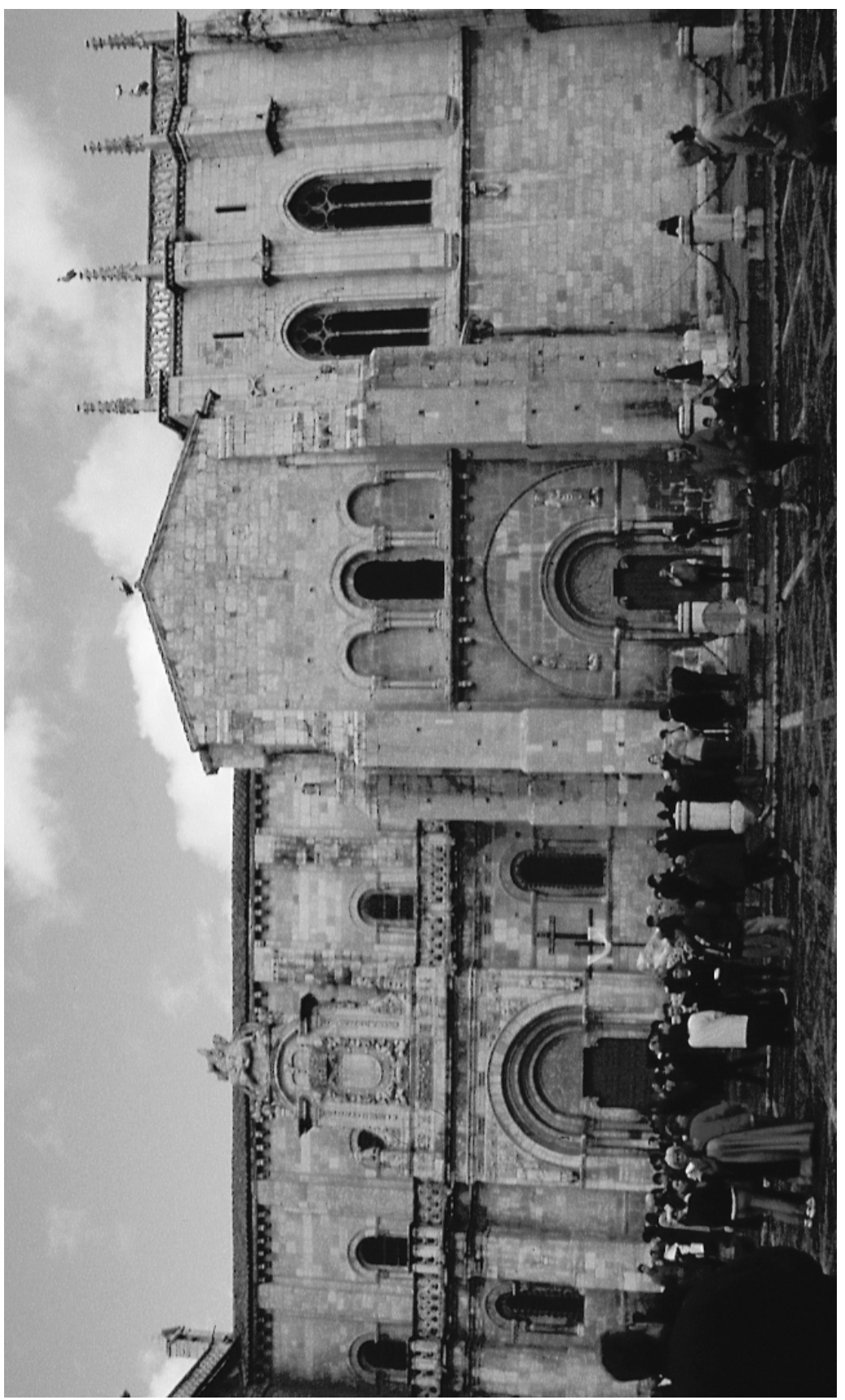

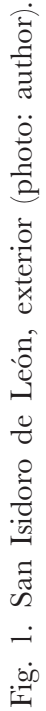

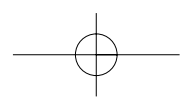


MARTIN-HARRIS_f15_373-412 7/29/05 1:16 Page) 401

READING THE WALLS

401

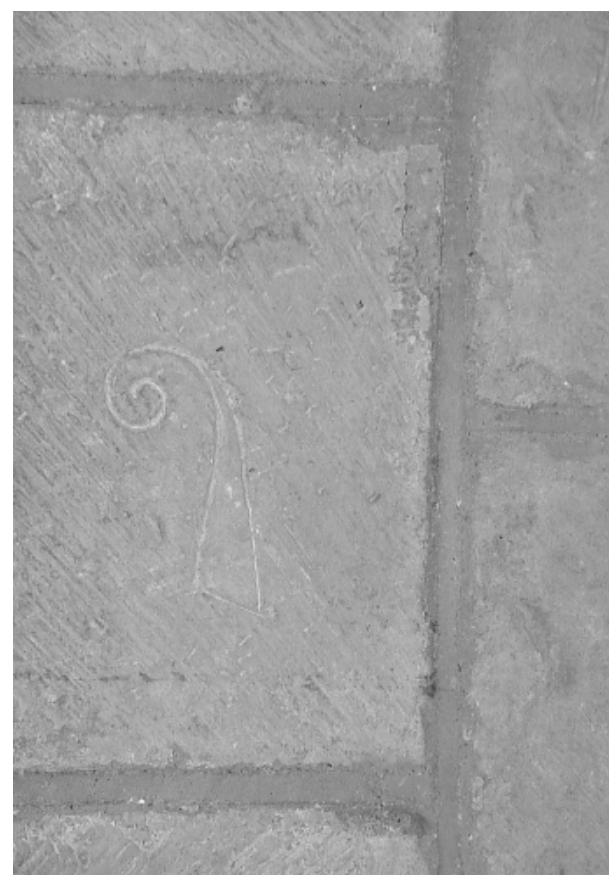

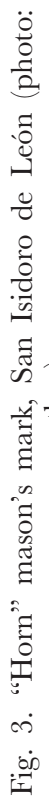
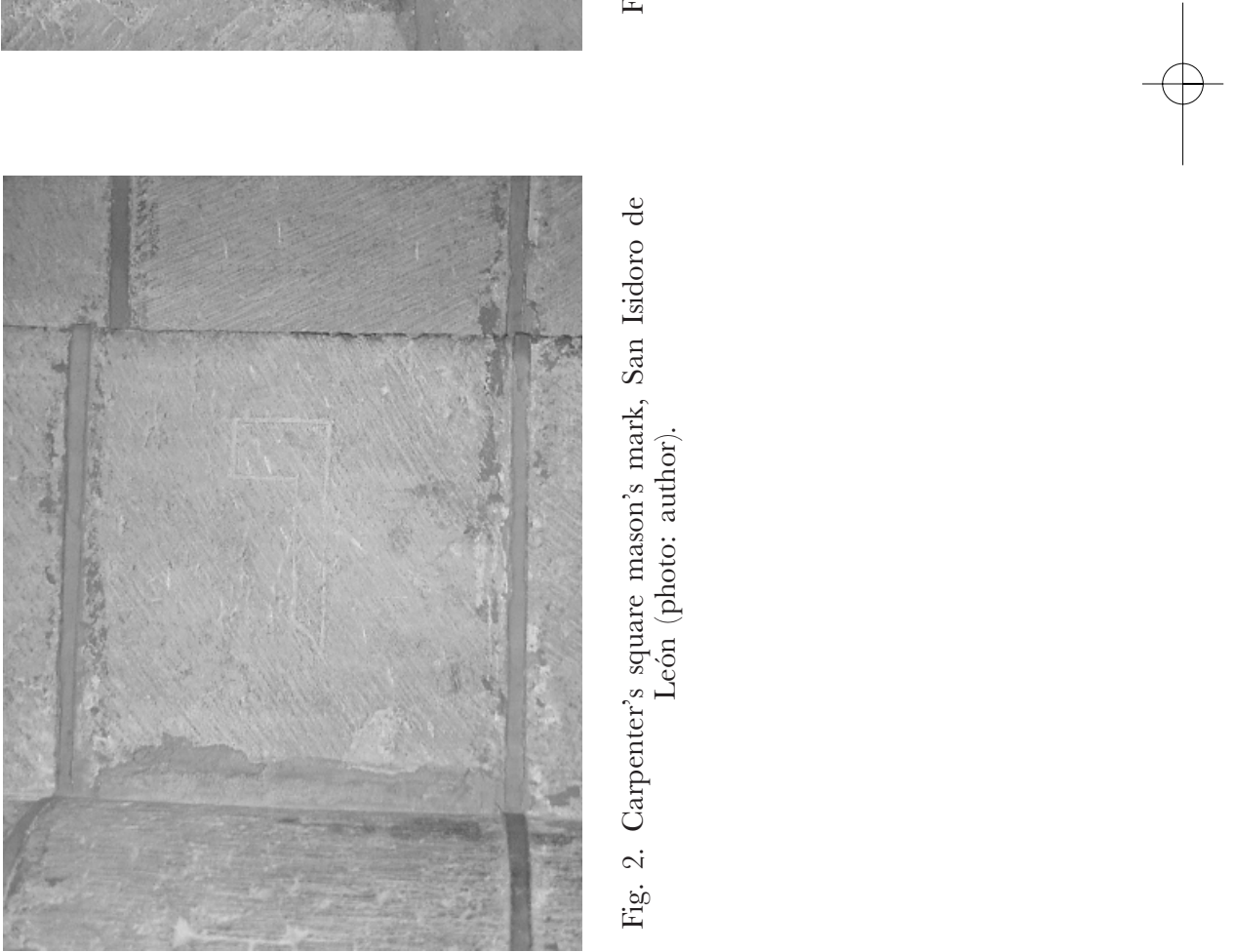

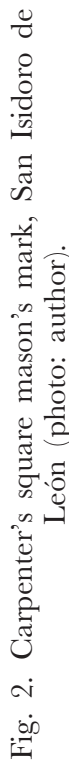

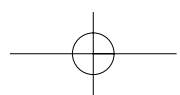


MARTIN-HARRIS_f15_373-412 7/29/05 1:16 Page) 402

402

THERESE MARTIN
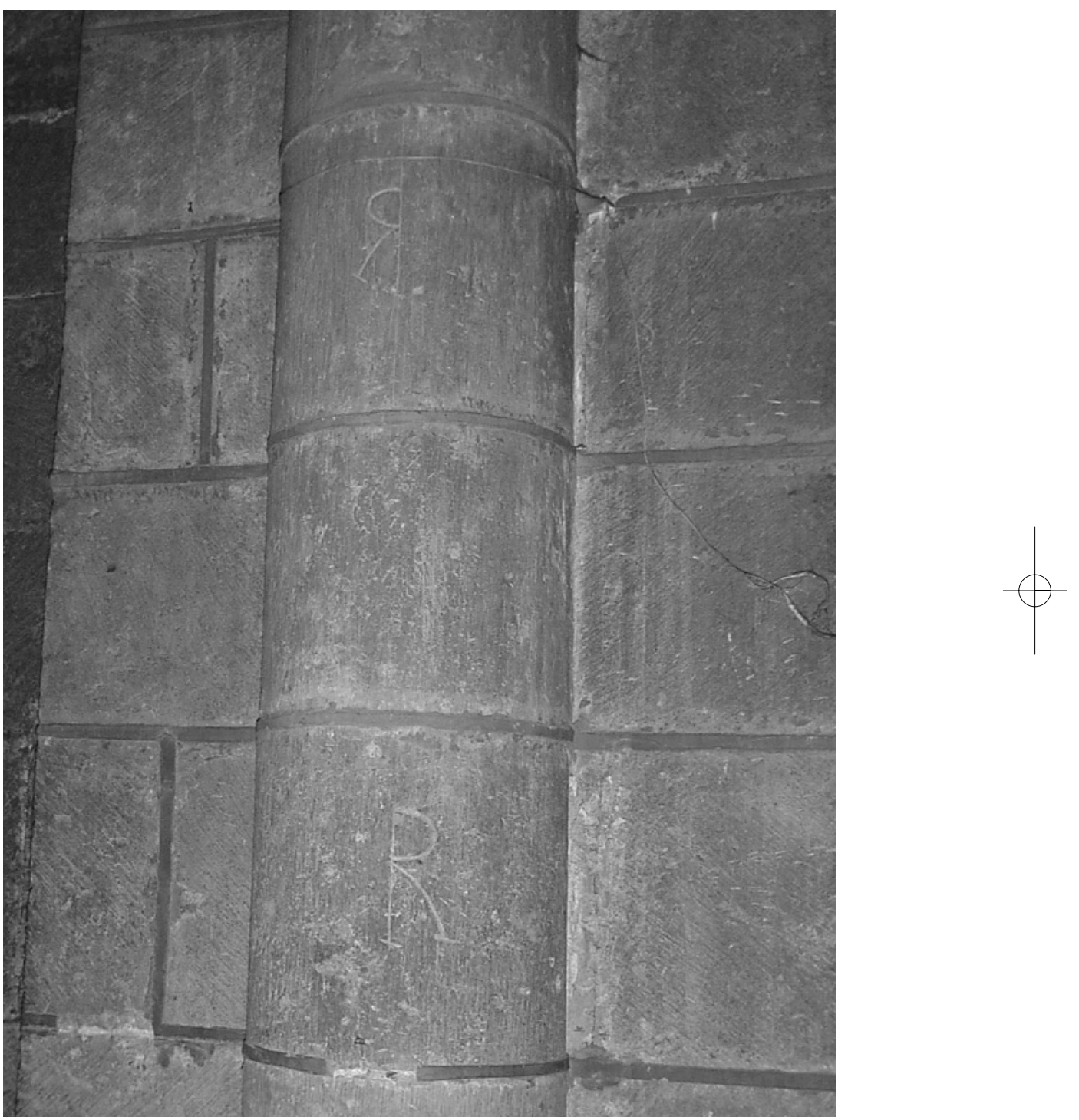

Fig. 4. R mason's mark, San Isidoro de León (photo: author). 

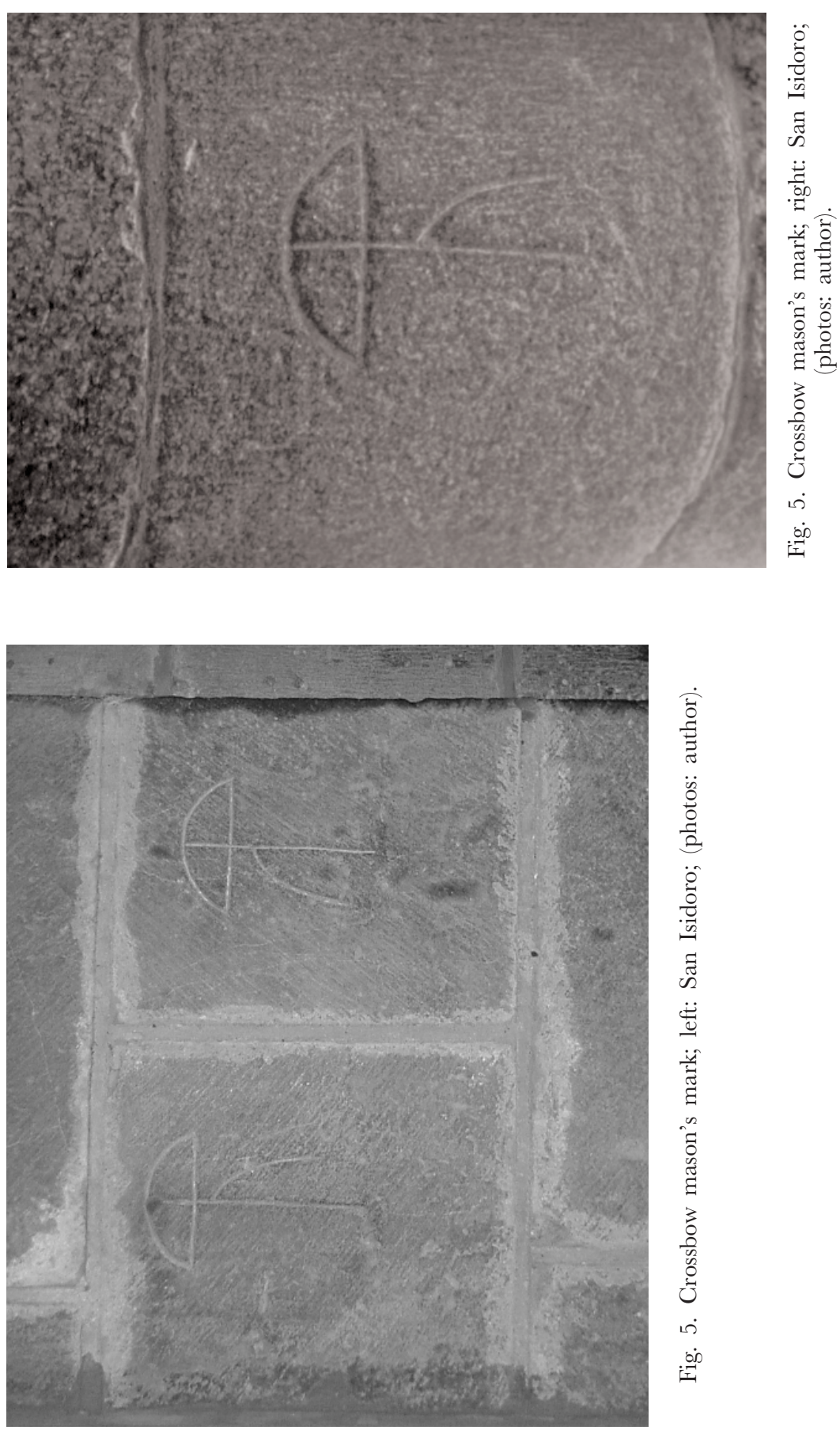

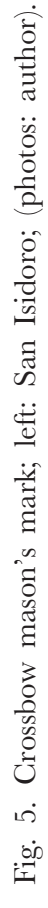
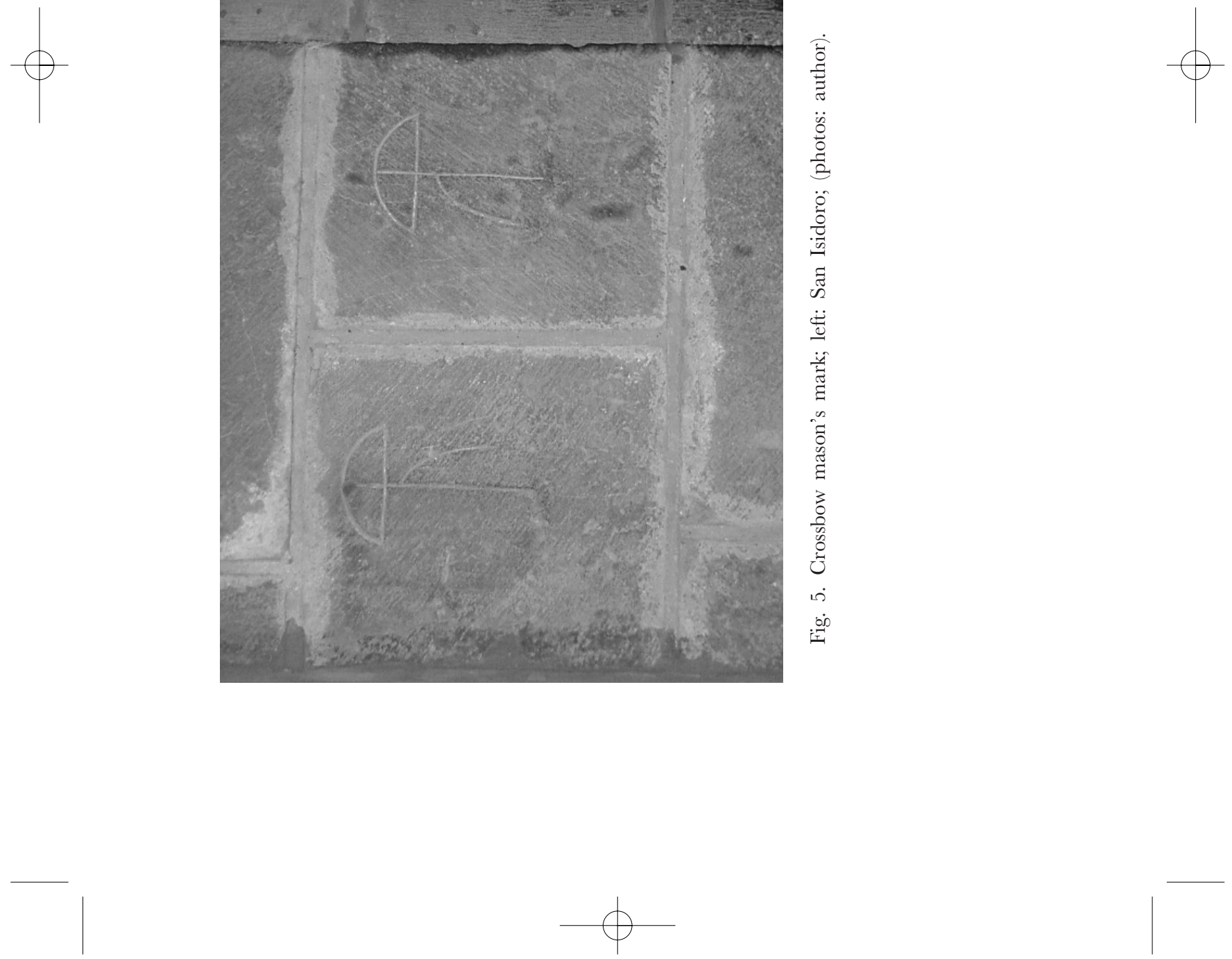

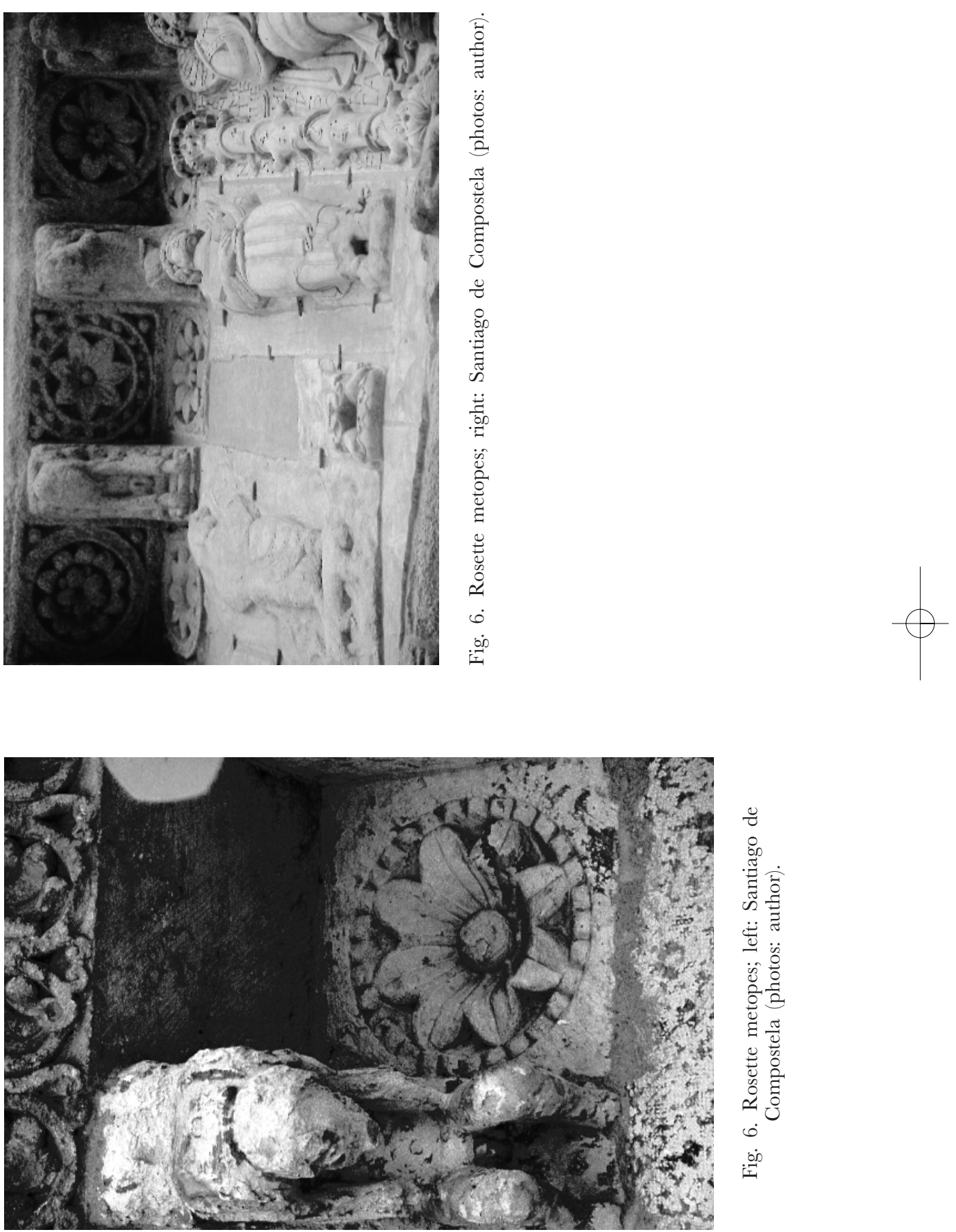

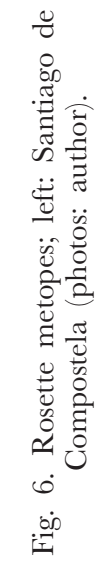




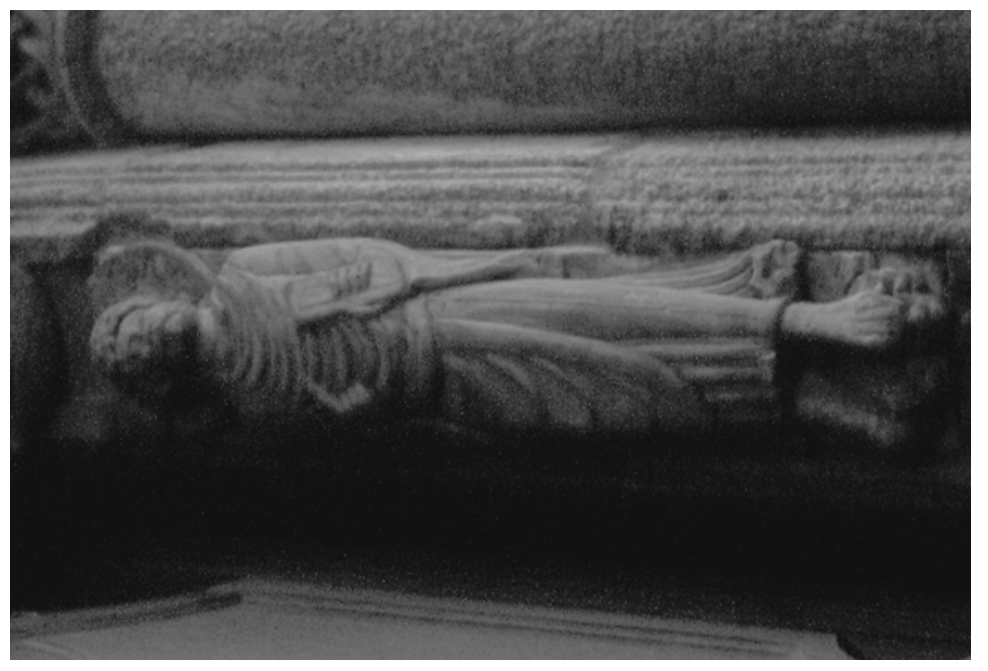

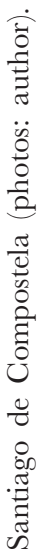
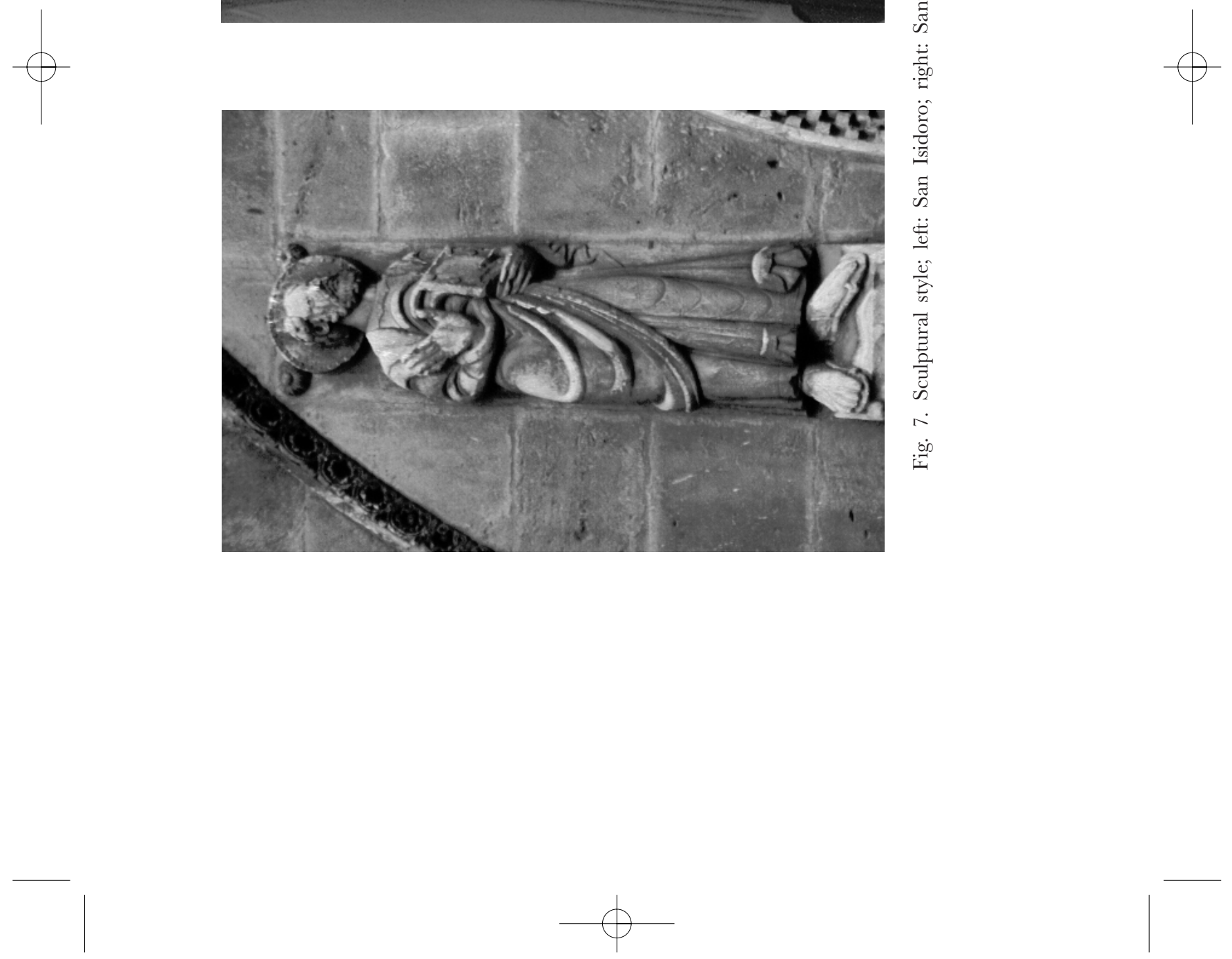


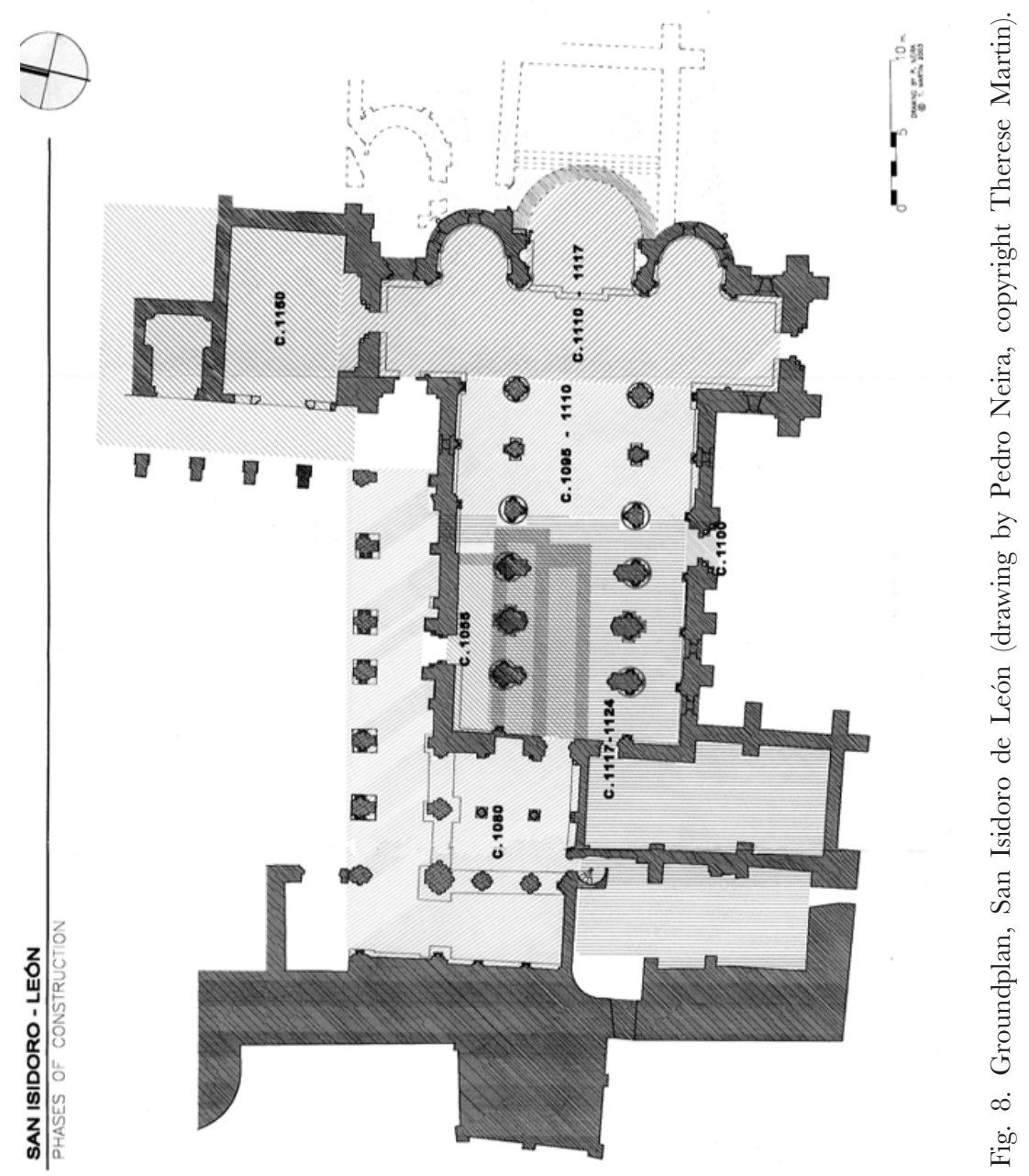




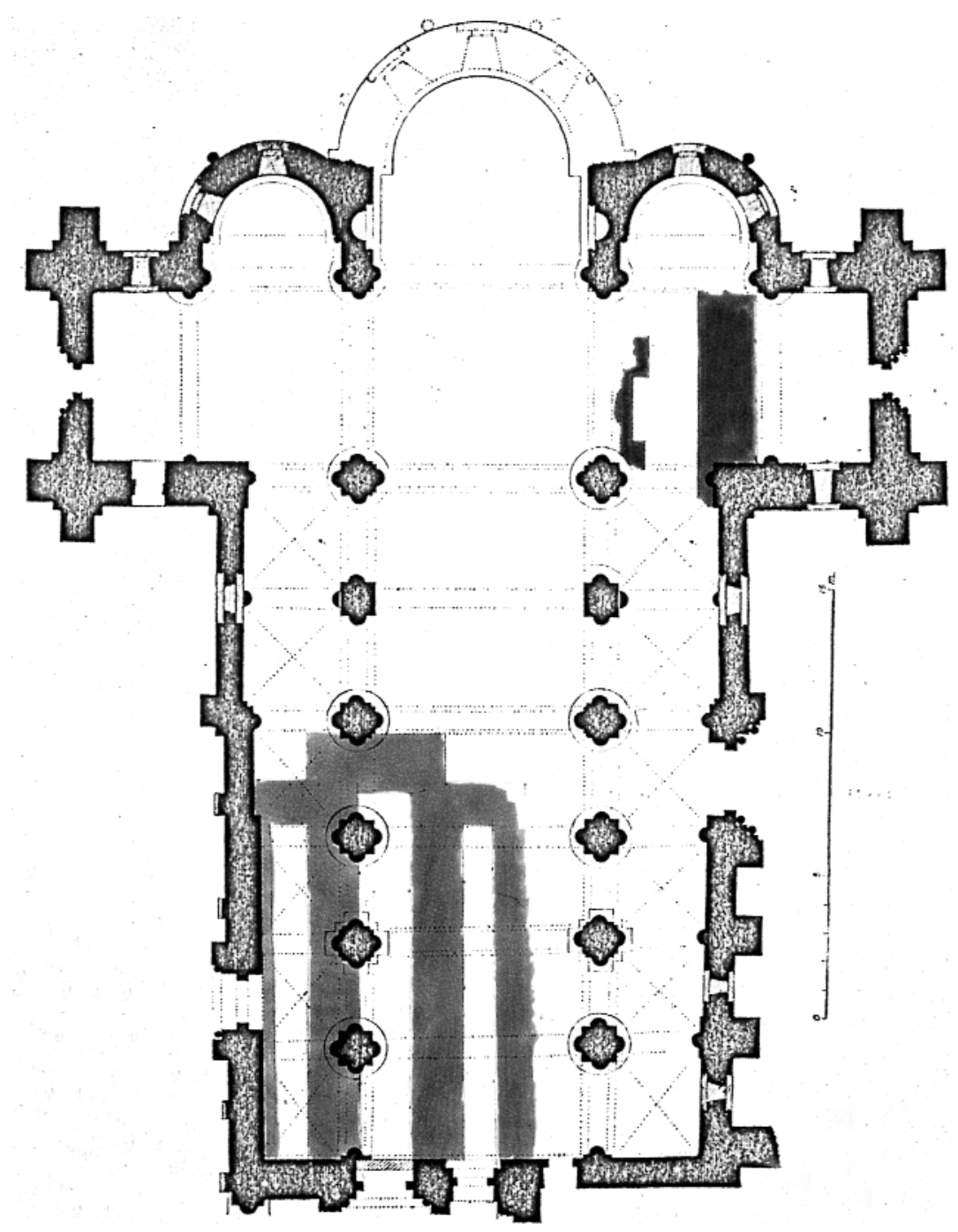

Fig. 9. Groundplan by Manuel Gómez-Moreno with foundations revealed 1970-71 by John Williams. 
MARTIN-HARRIS_f15_373-412 7/29/05 1:16 Page) 408

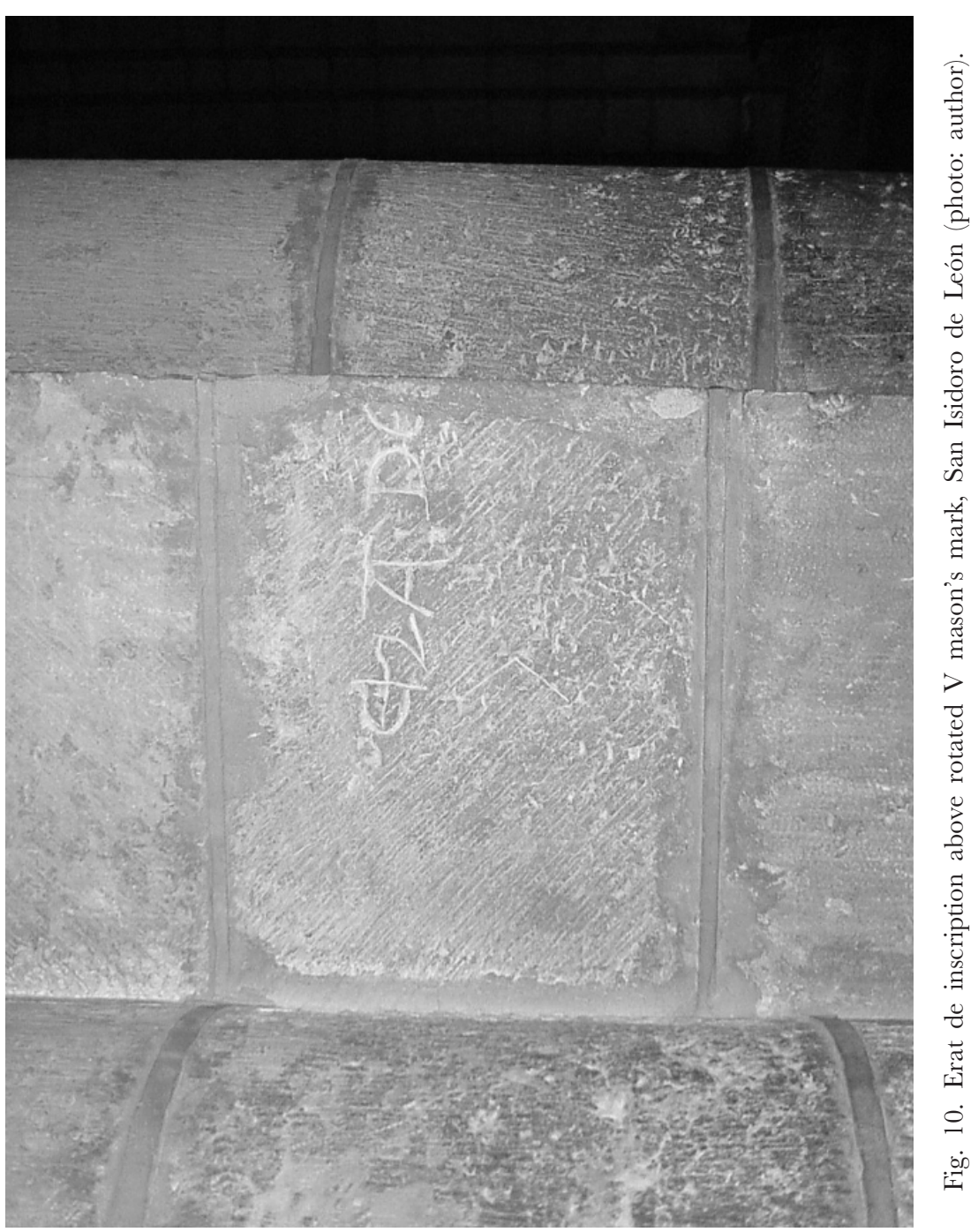


MARTIN-HARRIS_f15_373-412 7/29/05

1:16 Page 409

READING THE WALLS

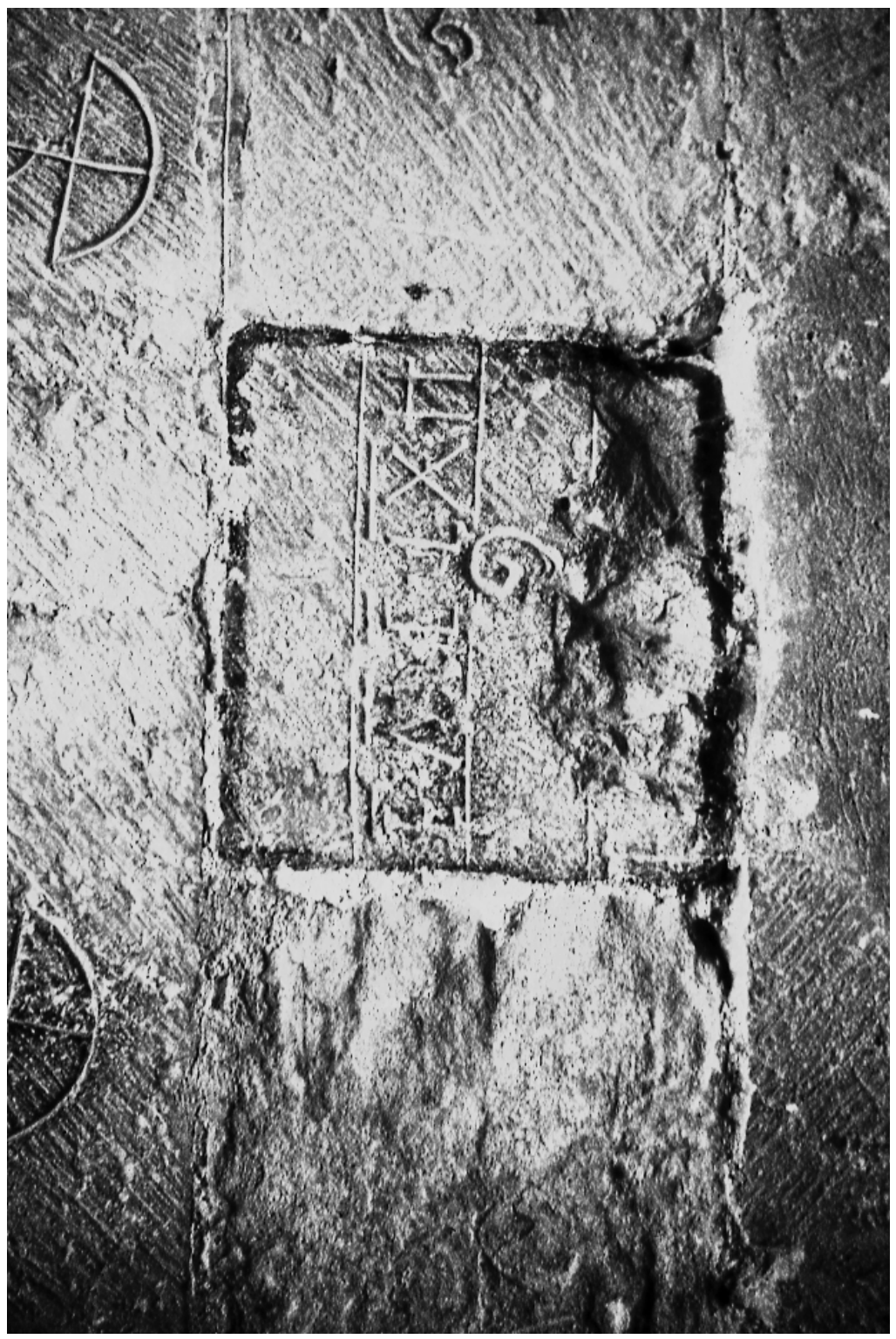

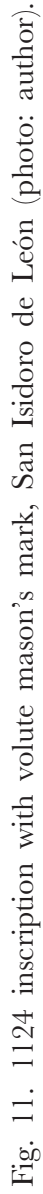

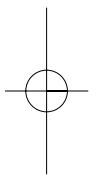



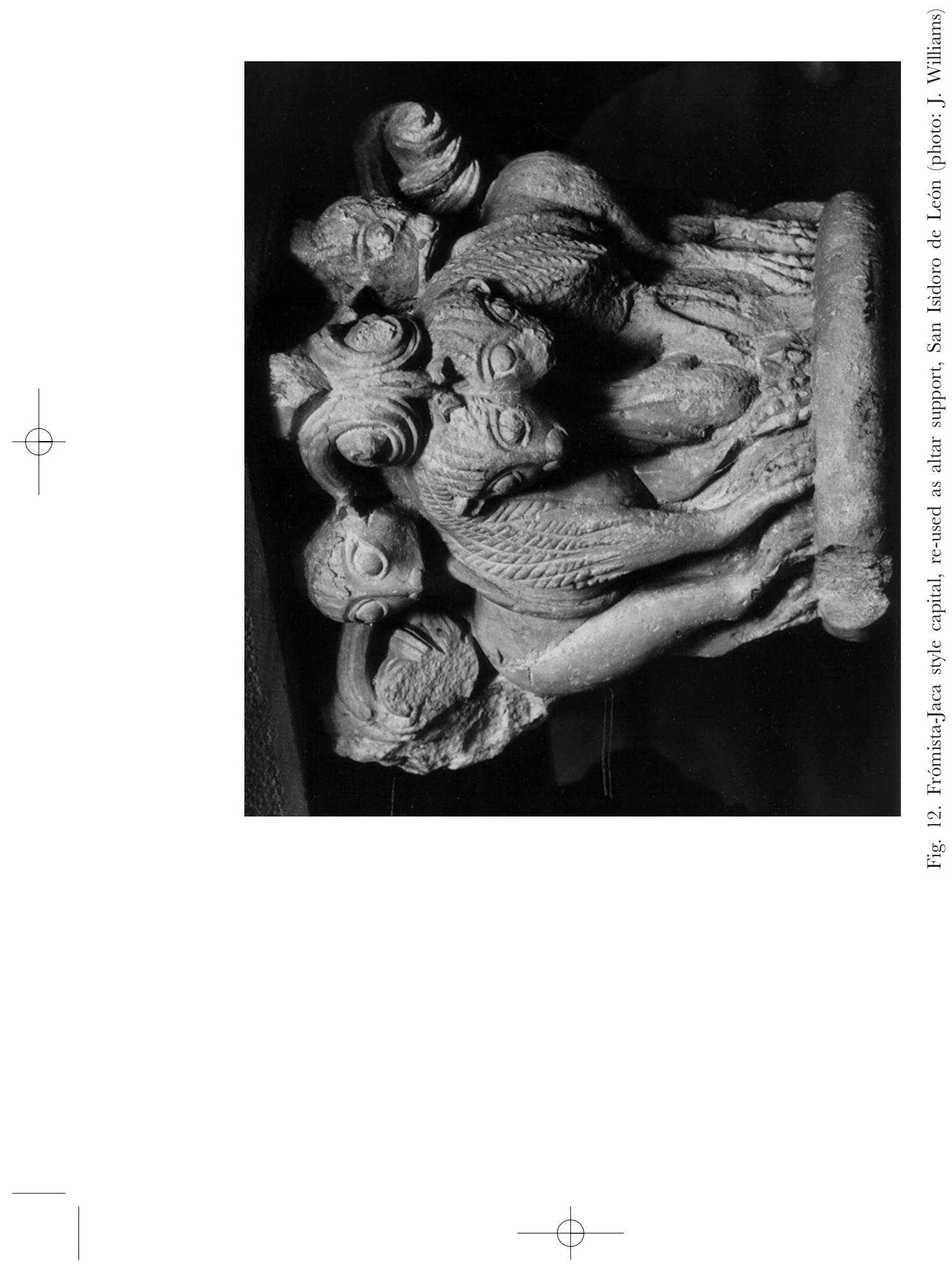


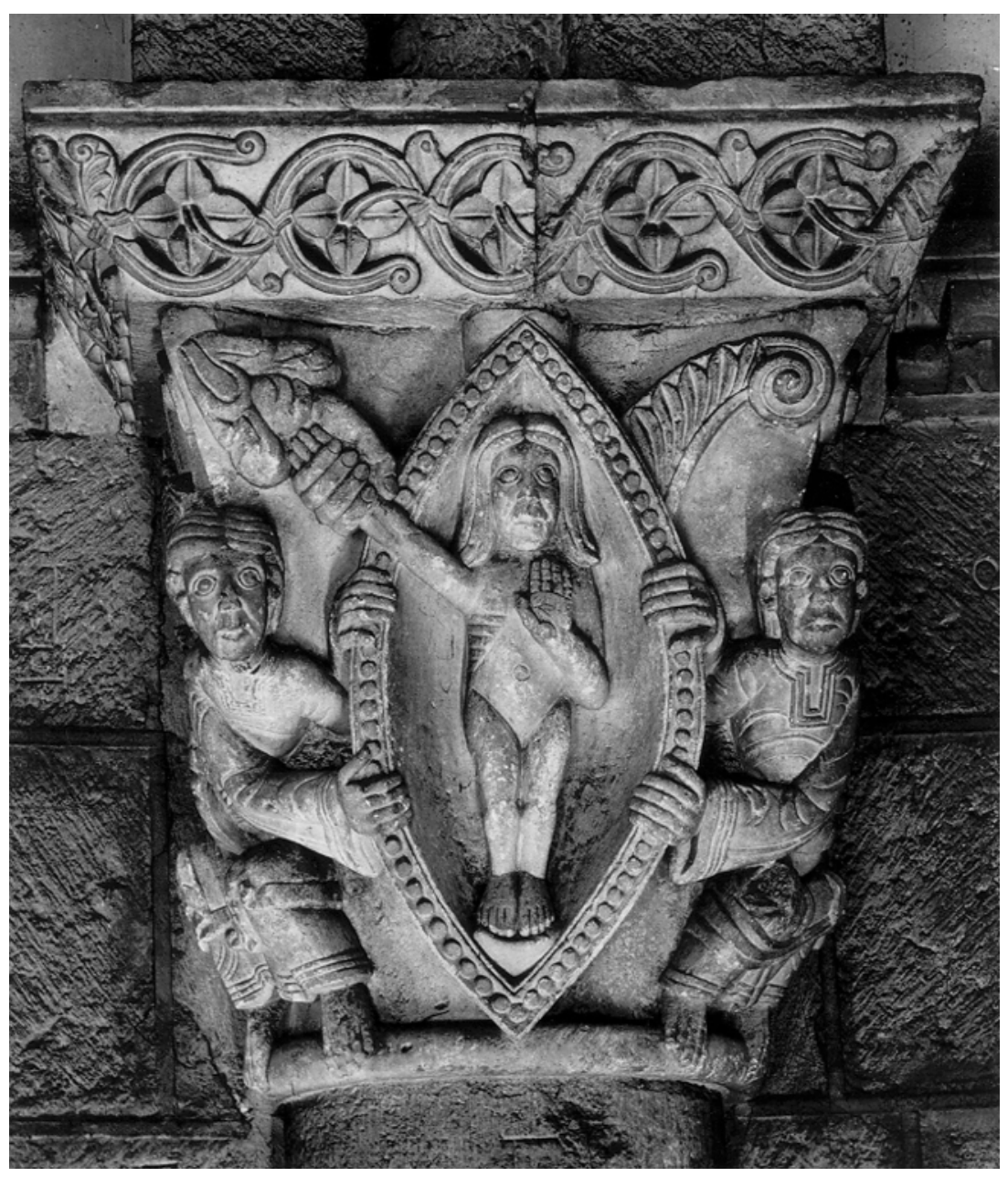

Fig. 13. Leonese-style capital, San Isidoro de León (photo: J. Williams). 
MARTIN-HARRIS_f15_373-412 7/29/05 1:17 Page) 412

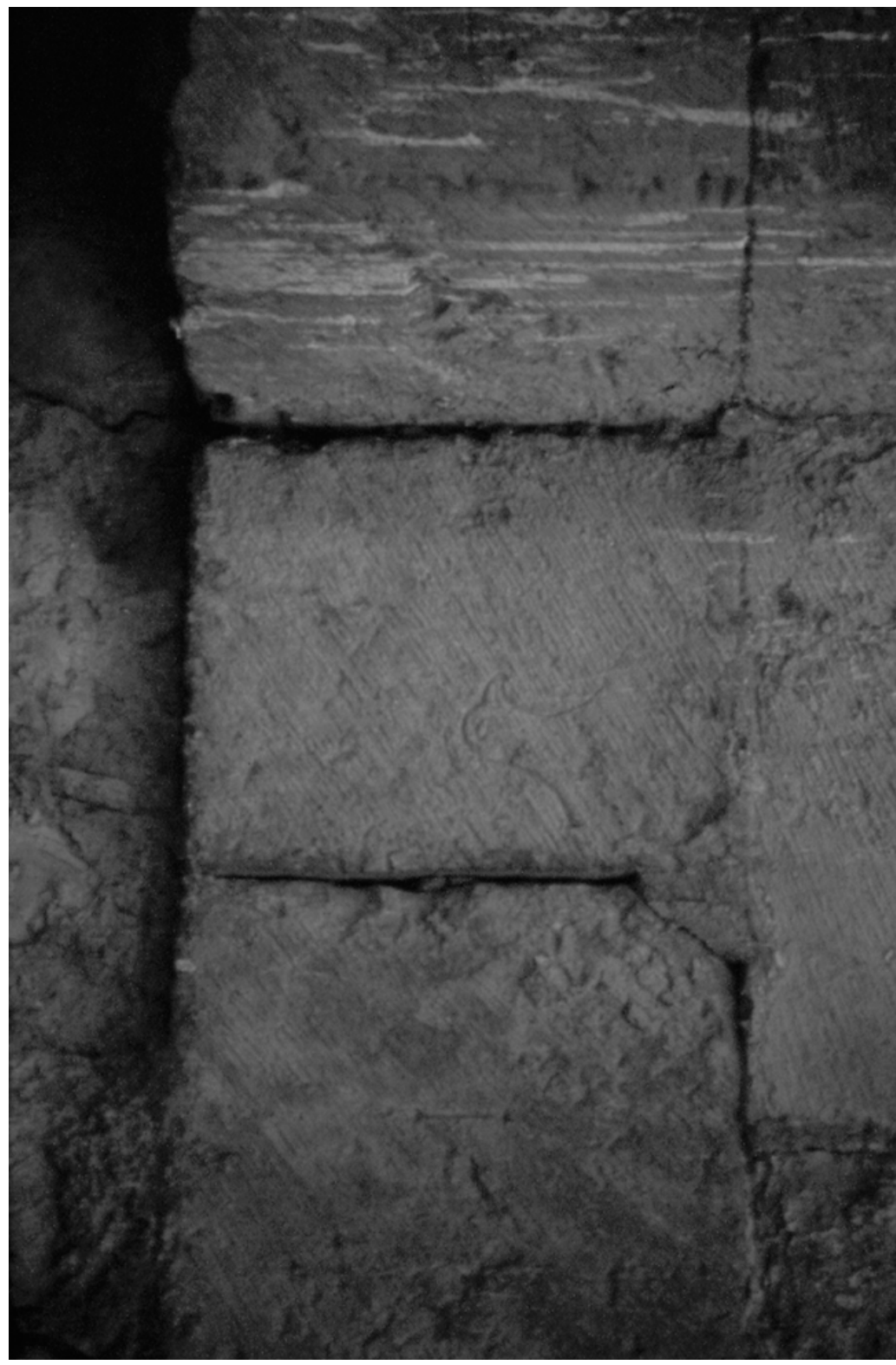

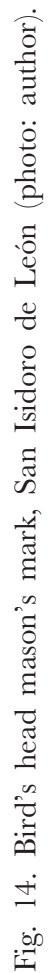
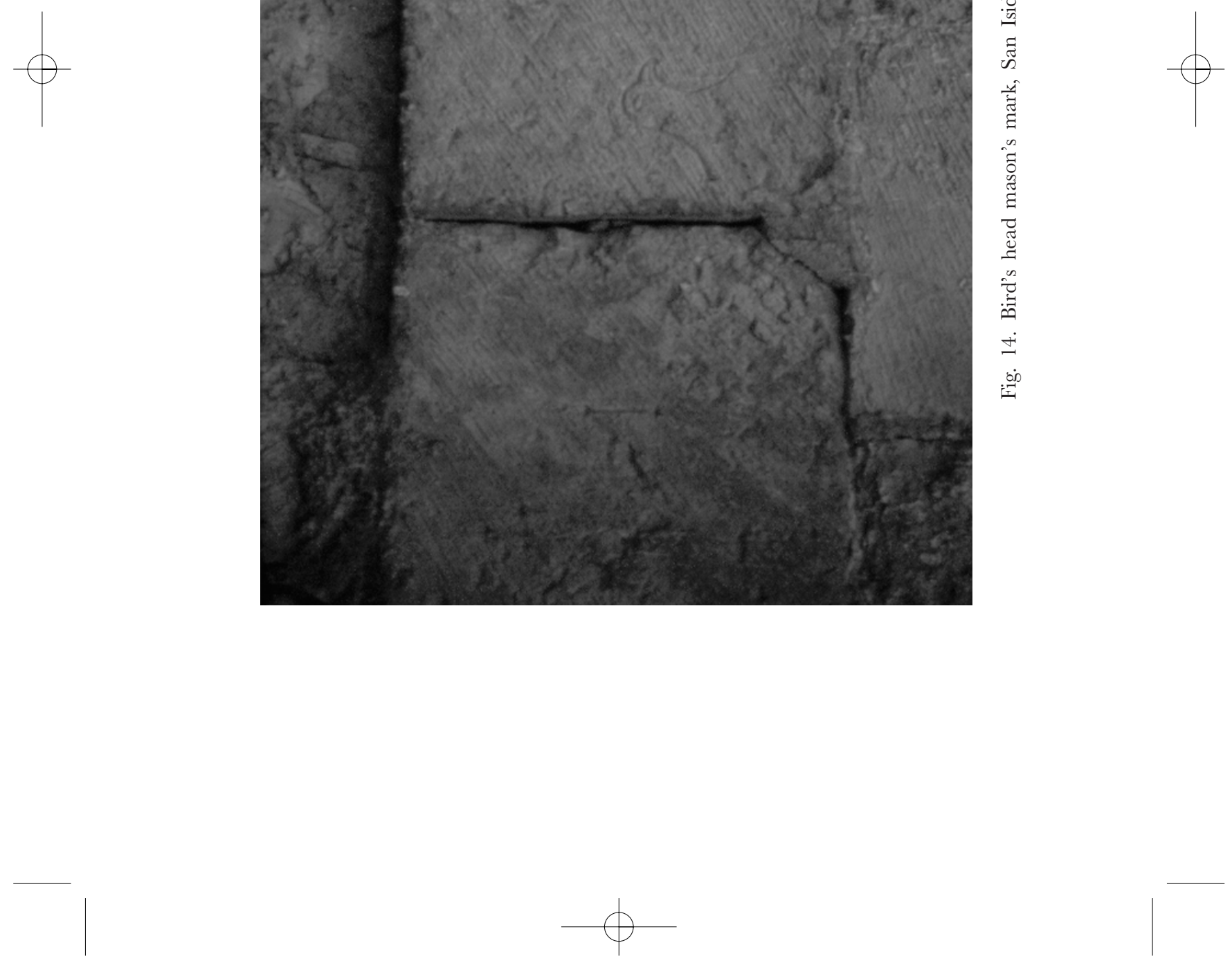